\title{
AXL and MET in Hepatocellular Carcinoma: A Systematic Literature Review
}

\author{
Chih-Hung Hsu ${ }^{a, b}$ Yi-Hsiang Huang ${ }^{c, d}$ Shi-Ming Lin ${ }^{e}$ Chiun Hsu, g \\ ${ }^{a}$ Graduate Institute of Oncology, National Taiwan University College of Medicine, Taipei, Taiwan; ${ }^{b}$ Department \\ of Oncology, National Taiwan University Hospital, Taipei, Taiwan; 'Institute of Clinical Medicine, National Yang \\ Ming Chiao Tung University School of Medicine, Taipei, Taiwan; 'Division of Gastroenterology and Hepatology, \\ Taipei Veterans General Hospital, Taipei, Taiwan; 'Department of Gastroenterology and Hepatology, Chang Gung \\ Memorial Hospital, Chang Gung University, Taoyuan, Taiwan; ${ }^{f}$ Graduate Institute of Oncology, National Taiwan \\ University College of Medicine, Taipei, Taiwan; ${ }^{9}$ National Taiwan University Cancer Center, Taipei, Taiwan
}

\section{Keywords}

AXL receptor tyrosine kinase $\cdot$ Cabozantinib $\cdot$ Hepatocellular carcinoma - Mesenchymal-to-epithelial transition receptor tyrosine kinase · Tumor microenvironment

\begin{abstract}
Background: Multikinase inhibitors (MKIs) have been shown to improve survival in patients with hepatocellular carcinoma (HCC) compared with placebo. Distinct from other MKIs, cabozantinib has inhibitory activity for both AXL and MET. This review considers the literature elucidating the role of AXL and MET in HCC progression, treatment resistance, and immunomodulation. A systematic search of the PubMed database was conducted on November 16, 2020, and identified a total of 174 search results. A further 36 potentially relevant articles were identified based on the authors' knowledge. After initial screening by title/abstract, 159 underwent full-text screening and we identified 69 original research articles reporting empirical data from in vitro or in vivo models of HCC evaluating the effects of manipulating AXL or MET signaling on tumorigenic behavior. Summary: AXL expression is highly correlated with HCC progression and outcomes and has been reported to be involved in transforming growth factor- $\beta$ and the regulation of PI3K/AKT, ERK/MAPK, and CCN proteins. MET protein expression is increased in HCC with
\end{abstract}

karger@karger.com
www.karger.com/lic

Karger'?

GOPEN ACCESS
(C) 2022 The Author(s)

Published by S. Karger AG, Basel

This is an Open Access article licensed under the Creative Commons Attribution-NonCommercial-4.0 International License (CC BY-NC) (http://www.karger.com/Services/OpenAccessLicense), applicable to the online version of the article only. Usage and distribution for commercial purposes requires written permission. the highest histological grade and has been reported to be involved in the regulation of PI3K/AKT, PLCY/DAG/PKC, and MAPK/ERK signaling. Both AXL and MET are key regulators of sorafenib resistance in HCC. In terms of immunomodulation, there are data to indicate that AXL and MET interact with the immune components of the tumor microenvironment and promote tumorigenesis and treatment resistance. In addition, AXL was found to play a potential role in the development of a protumorigenic neutrophil phenotype in HCC. Combined inhibition of MET and programmed cell death protein resulted in additive reduction of $\mathrm{HCC}$ cell growth. Key Messages: AXL and MET play key roles in HCC progression, treatment resistance, and immunomodulation. Continued development of drugs that target these receptor tyrosine kinases appears likely to represent a useful strategy to improve outcomes for patients with HCC.

\section{(C) 2022 The Author(s)}

Published by S. Karger AG, Basel

\section{Introduction}

Hepatocellular carcinoma (HCC) is the sixth most commonly diagnosed cancer in the world [1]. Many patients present with advanced disease [2], for which the

All authors contributed equally and are joint first authors.
Correspondence to:

Shi-Ming Lin, lsmpaicyto@gmail.com

Chiun Hsu, hsuchiun@ntu.edu.tw 
prognosis is poor [1]. Approximately $80 \%$ of HCC cases occur in patients with liver cirrhosis [2]. An accumulation of somatic genomic and epigenomic alterations, a few of which are associated with key signaling pathways, may drive the development of HCC [2].

A number of multikinase inhibitors (MKIs), among them sorafenib, regorafenib, and cabozantinib, have been shown to improve survival in patients with HCC compared with placebo $[1,3]$. Sorafenib was the first approved treatment for HCC and remains one of the commonly used first-line therapies. The effects of sorafenib on tumor response, however, were modest in pivotal clinical trials, with partial response rates of $2-3 \%$ and disease control rates of $35-43 \%[4,5]$. The majority of patients with HCC who receive first-line sorafenib still progress, often acquiring resistance to treatment within 3-6 months [6].

Receptor tyrosine kinases (RTKs) are key regulators of cell growth, proliferation, migration, and angiogenesis [7]. Dysregulation of RTKs, through functional mutations or overexpression, can disrupt these natural cellular processes and contribute to tumorigenesis $[7,8]$. A wide range of RTKs are also expressed on immune cells, including vascular endothelial growth factor receptor (VEGFR), mesenchymal-to-epithelial transition (MET), RET, recepteur d'origine nantais (RON), KIT, and the tumor-associated macrophage (TAM) RTKs, namely TYRO3, AXL, and MER proto-oncogene tyrosine kinase (MERTK) [9-12]. Any dysregulation of RTKs, therefore, has the potential not only to contribute to tumorigenesis but also to affect immune-mediated destruction of the tumor cells that develop.

Expression of RTKs can be influenced by the tumor microenvironment (TME), which has implications for cancer progression. For example, hypoxic conditions within the TME have been shown to increase AXL expression and promote metastasis via the transcription factor hypoxia-inducible factor $[13,14]$. More generally, upregulation of RTK ligands in the TME, and the effects of this on RTK-expressing immune cells, can modulate immune system components $[12,15]$. Such effects are typically immunosuppressive, inhibiting innate and adaptive immune-mediated destruction of cancer cells, and, thereby, supporting tumor progression and proliferation $[15,16]$. Cabozantinib was recently shown to increase overall survival (OS) and progression-free survival (PFS) in patients with advanced HCC who had received previous treatment with sorafenib [3], leading to its approval in the USA and Europe for patients with HCC who have been previously treated with sorafenib $[17,18]$.

AXL and MET in Hepatocellular

Carcinoma
A characteristic of cabozantinib that distinguishes it from other MKIs approved for HCC is that it has inhibitory activity against both AXL and MET [19]. Aberrant signaling of both of these RTKs has been linked to tumor development, metastases (e.g., bone), and progression [20-22], and to sorafenib resistance in patients with HCC $[23,24]$. In addition, members of the TAM receptor family, which includes AXL, are key regulators of innate immune-system activity against tumors [15]. There is therefore significant interest in the therapeutic targeting of AXL and MET in terms of their potential implications for HCC progression, treatment resistance, and immunomodulation. This review considers the literature elucidating the role of AXL and MET in HCC progression, treatment resistance, and immunomodulation.

\section{Methods}

A systematic search of the PubMed database was conducted on November 16, 2020, to identify English language, original research articles reporting empirical data from in vitro or in vivo models of HCC evaluating the effects of modulation of AXL or MET signaling on tumorigenic properties (see online suppl. methods for the full search string; for all online suppl. material, see www.karger. com/doi/10.1159/000520501). All publications were de-duplicated and unique articles screened for eligibility. Publications were initially screened by title/abstract, with those deemed potentially relevant then undergoing full-text screening. Articles were not limited by publication type, date, or study design. Additional records were identified based on the authors' knowledge and hand searching the reference lists of key publications. The final list of eligible articles was reviewed and approved by the full author group before data extraction. Data were extracted in duplicate. No risk of bias assessment was conducted for the included studies. Targeted searches of recent and ongoing clinical trials of AXL and MET inhibitors in HCC were also conducted on June 26, 2020 (online suppl. methods), to support discussion of the literature-review findings in the context of investigational therapies for HCC (Table 2).

\section{Search Results}

Of 174 abstracts screened, 69 were deemed relevant and were included in this review. In total, 51 articles were excluded based on screening of the title/abstract, and 90 were excluded based on full-text screening (online suppl. Fig. 1). Of the included articles, 25 provided data on the implications of AXL or MET signaling modulation on tumor progression $(n=17)$, treatment resistance $(n=7)$, and immunomodulation $(n=3)$; these key studies are summarized in detail in Table 1.

Liver Cancer 2022;11:94-112 
Table 1. Preclinical in vitro and in vivo evidence of AXL- and MET-specific effects on HCC cell phenotypes

\begin{tabular}{|c|c|c|c|c|}
\hline Reference & HCC models & RTK manipulation & Phenotypic effects & Role in HCC \\
\hline \multirow[t]{5}{*}{ Reichl et al. [37] } & \multirow[t]{3}{*}{ 3sp (mesenchymal) } & \multirow[t]{2}{*}{ AXL stimulation with GAS6 } & Increased cell migration (4-fold) & \multirow{5}{*}{$\begin{array}{l}\text { Progression: increased AXL signaling } \\
\text { enhances metastatic properties, } \\
\text { including resistance to TGF- } \beta \text {-mediated } \\
\text { cell death }\end{array}$} \\
\hline & & & Increased cell invasion (3-fold) & \\
\hline & & AXL knockdown & $\begin{array}{l}\text { Increased cell death upon } \\
\text { exposure to TGF- } \beta\end{array}$ & \\
\hline & \multirow[t]{2}{*}{ Mouse PLC (AXL-deficient) xenograft } & \multirow[t]{2}{*}{$\begin{array}{l}\text { Mouse PLC-AXL (AXL-expressing) } \\
\text { xenograft }\end{array}$} & $\begin{array}{l}\text { Increased tumor growth versus } \\
\text { PLC xenograft }\end{array}$ & \\
\hline & & & $\begin{array}{l}\text { More frequent metastasis versus } \\
\text { PLC xenograft }\end{array}$ & \\
\hline \multirow[t]{4}{*}{ Haider et al. [38] } & HLF (mesenchymal) & AXL knockout & Inhibition of CXCL5 secretion & \multirow{4}{*}{$\begin{array}{l}\text { Progression and immunomodulation: } \\
\text { AXL mediates TGF- } \beta \text {-induced expression } \\
\text { of } C X C L 5 \text { and contributes to neutrophil } \\
\text { recruitment in HCC }\end{array}$} \\
\hline & \multirow{2}{*}{$\begin{array}{l}\text { HLF-T (HLF after } 10 \text { days exp. to TGF- } \beta \text { ) } \\
\text { Enhanced CXCL5 ( } 33 \text {-fold vs. HLF) } \\
\text { Enhanced neutrophil recruitment ( } \sim 2 \text {-fold vs. HLF) }\end{array}$} & AXL knockout & $\begin{array}{l}\text { Inhibition of enhanced CXCL5 } \\
\text { secretion }\end{array}$ & \\
\hline & & $\begin{array}{l}\text { AXL-specific inhibition with } \\
\text { TP0903 }\end{array}$ & $\begin{array}{l}\text { Inhibition of enhanced neutrophil } \\
\text { recruitment }\end{array}$ & \\
\hline & $\begin{array}{l}\text { HLF-CXCL5 (ectopic CXCL5) } \\
\text { Enhanced CXCL5 (2,000-fold vs. HLF) } \\
\text { Enhanced neutrophil recruitment ( 2-fold vs. HLF) }\end{array}$ & $\begin{array}{l}\text { AXL-specific inhibition with } \\
\text { TP0903 }\end{array}$ & $\begin{array}{l}\text { No effect on neutrophil } \\
\text { recruitment }\end{array}$ & \\
\hline \multirow[t]{7}{*}{ Pinato et al. [24] } & SK-HEP-1, Huh7, SNU-449, Hep3B, and C3A & AXL-specific inhibition with R428 & Growth inhibition & \multirow{7}{*}{$\begin{array}{l}\text { Progression and resistance: increased } \\
\text { AXL signaling enhances HCC metastatic } \\
\text { properties and contributes to sorafenib } \\
\text { resistance }\end{array}$} \\
\hline & \multirow{3}{*}{$\begin{array}{l}\text { SK-HEP-1 (mesenchymal) } \\
\text { AXL overexpression } \\
\text { Sorafenib IC }{ }_{50} \text { (cell viability) }=4.57 \mu \mathrm{M}\end{array}$} & $\begin{array}{l}\text { AXL knockdown } \\
\text { AXL-specific inhibition with R428 }\end{array}$ & $\begin{array}{l}\text { Impaired/altered colony } \\
\text { formation }\end{array}$ & \\
\hline & & AXL knockdown & $\begin{array}{l}\text { Sorafenib } \mathrm{IC}_{50} \text { decreased to } 3.85 \\
\mu \mathrm{M}\end{array}$ & \\
\hline & & AXL-specific inhibition with R428 & Reduced migration and invasion & \\
\hline & \multirow{3}{*}{$\begin{array}{l}\text { SK-HEP-1-R (sorafenib-resistant SK-HEP-1) } \\
\text { Sorafenib IC } \text { C }_{50} \text { (cell viability) }=6.11 \mu \mathrm{M} \\
\text { AXL hyperphosphorylation } \\
\text { Enhanced migration and invasion }\end{array}$} & $\begin{array}{l}\text { AXL knockdown } \\
\text { AXL-specific inhibition with R428 }\end{array}$ & Reduced migration and invasion & \\
\hline & & AXL knockdown & $\begin{array}{l}\text { Sorafenib } I C_{50} \text { decreased to } 4.16 \\
\mu \mathrm{M}\end{array}$ & \\
\hline & & AXL-specific inhibition with R428 & $\begin{array}{l}\text { Increased apoptosis (dose } \\
\text { dependent and synergistic with } \\
\text { sorafenib) }\end{array}$ & \\
\hline \multirow[t]{2}{*}{ Xu et al. [39] } & MHCC97-H (highly metastatic MHCC97 cells) & AXL knockdown & Reduced invasion & \multirow{2}{*}{$\begin{array}{l}\text { Progression: increased AXL signaling } \\
\text { enhances HCC metastatic properties }\end{array}$} \\
\hline & Mouse MHCC97-H xenograft & AXL knockdown & Reduced tumor formation & \\
\hline \multirow[t]{3}{*}{ Lee et al. [40] } & \multirow{3}{*}{$\begin{array}{l}\text { HA22T } \\
\text { AXL highly activated versus other HCC cell lines } \\
\text { Mahlavu } \\
\text { AXL moderately activated versus other HCC cell } \\
\text { lines }\end{array}$} & AXL stimulation with GAS6 & $\begin{array}{l}\text { Enhanced invasion (done for } \\
\text { HA22T only) }\end{array}$ & \multirow[t]{3}{*}{$\begin{array}{l}\text { Progression: increased AXL signaling } \\
\text { enhances HCC metastatic properties }\end{array}$} \\
\hline & & AXL knockdown & $\begin{array}{l}\text { Reduced invasion } \\
\text { No effect on cell survival or } \\
\text { proliferation }\end{array}$ & \\
\hline & & $\begin{array}{l}\text { AXL-specific inhibition with } \\
\text { bosutinib }\end{array}$ & Reduced invasion & \\
\hline \multirow[t]{7}{*}{ He et al. [43] } & \multirow{5}{*}{$\begin{array}{l}\text { Hca-F } \\
\text { AXL overexpressed (vs. Hca-P) } \\
\text { High metastatic potential (vs. Hca-P) } \\
\text { Increased proliferation (vs. Hca-P) }\end{array}$} & AXL stimulation ( $24 \mathrm{~h}$ ) with GAS6 & Reduced AXL protein expression & \multirow[t]{7}{*}{$\begin{array}{l}\text { Progression: increased AXL signaling } \\
\text { enhances HCC metastatic properties }\end{array}$} \\
\hline & & & $\begin{array}{l}\text { Reduced migration and invasion } \\
\text { (effect mitigated in AXL } \\
\text { knockdown) }\end{array}$ & \\
\hline & & AXL knockdown & Reduced proliferation & \\
\hline & & & Impaired colony formation & \\
\hline & & & Reduce motility and invasion & \\
\hline & \multirow[t]{2}{*}{ Mouse Hca-F xenograft } & AXL stimulation with GAS6 & $\begin{array}{l}\text { Reduced migration and invasion } \\
\text { (effect mitigated in AXL } \\
\text { knockdown) }\end{array}$ & \\
\hline & & AXL knockdown & Less frequent metastasis & \\
\hline
\end{tabular}


Table 1 (continued)

\begin{tabular}{|c|c|c|c|c|}
\hline Reference & HCC models & RTK manipulation & Phenotypic effects & Role in HCC \\
\hline Li et al. [45] & $\begin{array}{l}\text { Hca-P } \\
\text { Low metastatic potential } \\
\text { Hca-F } \\
\text { High metastatic potential }\end{array}$ & $\begin{array}{l}\text { MET stimulated phosphorylation } \\
\text { Blocking PI3K/AKT with } \\
\text { LY294002 and PLCY/DAG/PKC } \\
\text { with U73122 }\end{array}$ & $\begin{array}{l}\text { PI3K/AKT signaling activity greater } \\
\text { in Hca-P than Hca-F } \\
\text { PLC } / \text { DAG/PKC signaling activity } \\
\text { greater in Hca-F than in Hca-P }\end{array}$ & $\begin{array}{l}\text { Motility and migration: HGF modulates } \\
\text { cell motility and migration }\end{array}$ \\
\hline Li et al. [51] & $\begin{array}{l}\mathrm{Hca} / 16 \mathrm{~A} 3 \\
\text { High ganglioside GM3 expression }\end{array}$ & MET downregulation & $\begin{array}{l}\text { Downregulation of PI3K/AKT } \\
\text { signaling }\end{array}$ & Migration: MET modulates cell migration \\
\hline Steinway et al. [52] & $\begin{array}{l}\text { MHCC97-H MET KD } \\
\text { MET knockdown } \\
\text { MHCC97-H } \\
\text { MET+ }\end{array}$ & $\begin{array}{l}\text { Decreased expression of } \\
\text { phospho-AKT and phosphor-ERK } \\
\text { compared with control }\end{array}$ & Suppression of tumor growth & $\begin{array}{l}\text { Tumor growth: MET induces HCC tumor } \\
\text { growth }\end{array}$ \\
\hline Topel et al. [53] & $\begin{array}{l}\text { SNU-449 HOTAIR overexpression and SNU-449 } \\
\text { MOCK }\end{array}$ & $\begin{array}{l}\text { HOTAIR overexpression } \\
\text { suppressed MET protein } \\
\text { expression and activation, and } \\
\text { downstream AKT1, MAPK and } \\
\text { STAT3 }\end{array}$ & Increased survival ability & $\begin{array}{l}\text { Survival: MET suppression with HOTAIR } \\
\text { overexpression increases survival ability }\end{array}$ \\
\hline Rhee et al. [54] & SNU475 & $\begin{array}{l}\text { Increased phospho-MET and } \\
\text { phospho-ERK1/2 mRNA and } \\
\text { protein }\end{array}$ & $\begin{array}{l}\text { Expression of MET was a poor } \\
\text { prognostic factor for disease- } \\
\text { specific survival and disease-free } \\
\text { survival (human HCC tissue) }\end{array}$ & $\begin{array}{l}\text { Poor prognosis: reduced survival with } \\
\text { MET expression }\end{array}$ \\
\hline Fu et al. [55] & $\begin{array}{l}\text { MHCC97-L } \\
\text { High MET expression }\end{array}$ & $\begin{array}{l}\text { Increased phosphorylation of } \\
\text { MET, AKT and ERK }\end{array}$ & $\begin{array}{l}\text { Reversal of EMT with knockdown } \\
\text { of MET expression }\end{array}$ & $\begin{array}{l}\text { Invasion and apoptosis: reversal of EMT } \\
\text { with MET knockdown }\end{array}$ \\
\hline Dang et al. [56] & MHCC97-H & $\begin{array}{l}\text { Downregulated MET and PI3K/ } \\
\text { AKT signaling and CD } 44 \mathrm{~s} \\
\text { expression }\end{array}$ & $\begin{array}{l}\text { Promotes a mesenchymal and } \\
\text { tumor-initiating stem-like cells } \\
\text { phenotype }\end{array}$ & $\begin{array}{l}\text { Initiation: downregulation of CD44s } \\
\text { decreases tumor initiation }\end{array}$ \\
\hline Hu et al. [57] & $\begin{array}{l}\text { AKT and AKT/MET FVB/N mice } \\
\text { MET FVB/N mice } \\
\text { Wild-type FVB/N mice }\end{array}$ & $\begin{array}{l}\text { Activation of the AKT/mTOR and } \\
\text { Ras/MAPK cascades }\end{array}$ & $\begin{array}{l}\text { Liver tumor development in mice } \\
\text { that co-expressed AKT and MET }\end{array}$ & $\begin{array}{l}\text { Tumor growth: coactivation of AXT and } \\
\text { MET triggered rapid tumor growth }\end{array}$ \\
\hline Ling et al. [58] & Hepatocyte-specific $\beta$-catenin knockout mice & $\beta$-catenin knockout & $\begin{array}{l}\text { Tumor-promoting stromal } \\
\text { changes }\end{array}$ & $\begin{array}{l}\text { Tumor growth: } \beta \text {-catenin deficiency } \\
\text { accelerates liver tumor cell expansion }\end{array}$ \\
\hline Takeda et al. [59] & $\begin{array}{l}\text { MIInc/nc mice } \\
\text { Homozygous noncleavable mutations of } M I l \\
\text { HepG2 }\end{array}$ & $\begin{array}{l}\text { HGF/MET induced the activity of } \\
\text { MLL and ETS2 }\end{array}$ & $\begin{array}{l}\text { Impaired outgrowth of the cranial } \\
\text { nerve XII }\end{array}$ & $\begin{array}{l}\text { Invasion: HGF/MET induced the activity } \\
\text { of MLL/ETS2, which directly activated } \\
\text { transcription of } M M P 1 \text { and } M M P 3\end{array}$ \\
\hline Piguet et al. [60] & $\begin{array}{l}\text { NIH3T3 } \\
\text { Constitutive kinase activity of M1268T and } \mathrm{Y} 1428 \mathrm{H} \\
\text { (MET-mutated variants) }\end{array}$ & $\begin{array}{l}\text { Reduction in VEGF levels in } \\
\text { M1268T but not } \mathrm{Y} 1248 \mathrm{H}\end{array}$ & $\begin{array}{l}\text { Antitumor activity and reduction } \\
\text { in microvessel density (in M1268T- } \\
\text { derived intrahepatic tumors) }\end{array}$ & $\begin{array}{l}\text { Tumor growth and angiogenesis: MET } \\
\text { inhibition was associated with a decrease } \\
\text { in the size and vascularization of HCC } \\
\text { tumors }\end{array}$ \\
\hline \multirow{9}{*}{$\begin{array}{l}\text { Firtina Karagonlar } \\
\text { et al. [23] }\end{array}$} & \multirow{9}{*}{$\begin{array}{l}\text { Huh7 (epithelial) } \\
\text { Low MET expression } \\
\text { Huh7-soR (sorafenib-resistant Huh7) } \\
\text { Increased MET expression versus Huh7 } \\
\text { Increased MET phosphorylation versus Huh7 } \\
\text { Increased migration versus Huh7 (9.6-fold) } \\
\text { Increased invasion versus Huh7 (19.8-fold) } \\
\text { Increased EGR1 and MMP9 expression } \\
\text { Mahlavu } \\
\text { Higher MET expression versus Huh7 } \\
\text { Mahlavu-soR (sorafenib-resistant Mahlavu) } \\
\text { Increased MET expression versus Mahlavu } \\
\text { Increased MET phosphorylation versus Mahlavu } \\
\text { Increased migration versus Mahlavu (8.6-fold) } \\
\text { Increased invasion versus Mahlavu (8.6-fold) } \\
\text { Increased EGR1 and MMP9 expression }\end{array}$} & \multirow{3}{*}{$\begin{array}{l}\text { MET-specific inhibition with } \\
\text { SU11274 in Huh7-soR cells }\end{array}$} & $27 \%$ reduction in migration & \multirow{9}{*}{$\begin{array}{l}\text { Progression and resistance: increased } \\
\text { MET signally contributes to enhanced } \\
\text { HCC metastatic properties associated } \\
\text { with sorafenib resistance }\end{array}$} \\
\hline & & & $33.3 \%$ reduction in invasion & \\
\hline & & & No change in apoptosis & \\
\hline & & \multirow{3}{*}{$\begin{array}{l}\text { MET-specific inhibition with } \\
\text { SU11274 in Mahlavu-soR cells }\end{array}$} & $55.8 \%$ reduction in migration & \\
\hline & & & $70.9 \%$ reduction in invasion & \\
\hline & & & Increased apoptosis & \\
\hline & & $\begin{array}{l}\text { MET-specific pharmacological } \\
\text { inhibition with SU11274 plus an } \\
\text { HGF antibody in Huh7-soR cells }\end{array}$ & $\begin{array}{l}48 \% \text { reduction in invasion (vs. } 32 \% \\
\text { [SU11274] and } 25 \% \text { [anti-HGF]) } \\
67.2 \% \text { rate of apoptosis (vs. } \sim 18 \% \\
\text { [SU } 11274 \text { ] and } \sim 20 \% \text { [anti-HGF]) }\end{array}$ & \\
\hline & & \multirow{2}{*}{$\begin{array}{l}\text { MET-specific pharmacological } \\
\text { inhibition with SU11274 plus an } \\
\text { HGF antibody in Mahlavu-soR } \\
\text { cells }\end{array}$} & $\begin{array}{l}67 \% \text { reduction in invasion (vs. } 35 \% \\
\text { [SU11274] and 30\% [anti-HGF]) }\end{array}$ & \\
\hline & & & $\begin{array}{l}67.2 \% \text { rate of apoptosis (vs. } 21.7 \% \\
\text { [SU11274] and } 23.7 \% \text { [anti-HGF]) }\end{array}$ & \\
\hline Chen and Xia [62] & HepG2 and Bel7404 & $\begin{array}{l}\text { miR-335 inhibition of MET } \\
\text { overexpression }\end{array}$ & $\begin{array}{l}\text { Abolished enhanced sorafenib } \\
\text { sensitivity after NEAT1 knockdown }\end{array}$ & $\begin{array}{l}\text { Resistance: NEAT1 may regulate drug } \\
\text { resistance of HCC cells via MET }\end{array}$ \\
\hline Han et al. [63] & $\begin{array}{l}\text { Huh7 and HepG2 (parental and sorafenib resistant) } \\
\text { MHCC- } 7721 \text { and MHCC-3M (parental and } \\
\text { sorafenib resistant) }\end{array}$ & $\begin{array}{l}\text { Elevated HGF production, and } \\
\text { upregulation of MET, AKT, and ERK } \\
\text { Dual inhibition of MET and AKT } \\
\text { with MK2206 and capmatinib }\end{array}$ & $\begin{array}{l}\text { Elevated HGF production } \\
\text { Suppression of sorafenib } \\
\text { resistance }\end{array}$ & $\begin{array}{l}\text { Resistance: MET and AKT are involved in } \\
\text { sorafenib resistance }\end{array}$ \\
\hline
\end{tabular}

AXL and MET in Hepatocellular Carcinoma
Liver Cancer 2022:11:94-112

DOI: $10.1159 / 000520501$ 
Table 1 (continued)

\begin{tabular}{|c|c|c|c|c|}
\hline Reference & HCC models & RTK manipulation & Phenotypic effects & Role in HCC \\
\hline Xiang et al. [66] & HepG2 and Huh7 & $\begin{array}{l}\text { Inhibition of phosphorylation of } \\
\text { AKT and ERK } 1 / 2 \text { with sorafenib } \\
\text { treatment } \\
\text { Combination of sorafenib and } \\
\text { HGF led to activation of MET, } \\
\text { AKT, and MAPK }\end{array}$ & $\begin{array}{l}\text { HGF-induced sorafenib resistance } \\
\text { by activating MET }\end{array}$ & $\begin{array}{l}\text { Resistance: HGF induces sorafenib } \\
\text { resistance }\end{array}$ \\
\hline Chen et al. [64] & $\begin{array}{l}\text { Huh7SR } \\
\text { Sorafenib resistant }\end{array}$ & $\begin{array}{l}\text { Inhibition of MET } \\
\text { phosphorylation with ANGPTL1 } \\
\text { by competing with HGF }\end{array}$ & Prevention of resistance & $\begin{array}{l}\text { Resistance: ANGPTL1 binds to MET and } \\
\text { blocks downstream pathways preventing } \\
\text { sorafenib resistance }\end{array}$ \\
\hline \multirow[t]{2}{*}{ Xiang et al. [65] } & \multirow[t]{2}{*}{ SK-HEP-1 and HepG2 } & MET stimulation with HGF & Increased migration & \multirow{2}{*}{$\begin{array}{l}\text { Progression: increased MET signaling } \\
\text { contributes to enhanced HCC metastatic } \\
\text { properties }\end{array}$} \\
\hline & & $\begin{array}{l}\text { Treatment of HGF/MET- } \\
\text { stimulated cells with } \\
\text { cabozantinib (MKI) }\end{array}$ & $\begin{array}{l}\text { Inhibition of HGF/MET-induced } \\
\text { migration }\end{array}$ & \\
\hline \multirow[t]{4}{*}{ Dong et al. [68] } & \multirow[t]{4}{*}{$\begin{array}{l}\text { HCC cell lines } \\
\text { SMMC-7721 and Hep3B } \\
\text { Macrophage cell lines } \\
\text { M1 and M2 (30-fold higher HGF secretion vs. M1) }\end{array}$} & $\begin{array}{l}\text { Incubation of HCC cells with M2 } \\
\text { (vs. M1) conditioned media }\end{array}$ & $\begin{array}{l}\text { Increased resistance to sorafenib } \\
\text { inhibition of colony formation, cell } \\
\text { proliferation, and migration }\end{array}$ & \multirow{4}{*}{$\begin{array}{l}\text { Resistance and immunomodulation: } \\
\text { increased secretion of HGF by M2 versus } \\
\text { M1 macrophages leads to sorafenib } \\
\text { resistance in HCC cells, as well as } \\
\text { recruitment of M2 versus M1 } \\
\text { macrophages, leading to positive } \\
\text { reinforcement of sorafenib resistance }\end{array}$} \\
\hline & & $\begin{array}{l}\text { MET stimulation with HGF in } \\
\text { HCC cells }\end{array}$ & $\begin{array}{l}\text { Increased resistance to sorafenib } \\
\text { inhibition in terms of colony } \\
\text { formation, cell proliferation, and } \\
\text { migration }\end{array}$ & \\
\hline & & $\begin{array}{l}\text { Inhibition of MET stimulation by } \\
\text { HGF using an anti-HGF antibody }\end{array}$ & $\begin{array}{l}\text { No change in resistance to } \\
\text { sorafenib inhibition in terms of } \\
\text { colony formation, cell } \\
\text { proliferation, or migration }\end{array}$ & \\
\hline & & $\begin{array}{l}\text { Exposure of } \mathrm{M} 2 \text { versus } \mathrm{M} 1 \text { cells } \\
\text { to HGF }\end{array}$ & $\begin{array}{l}\text { Chemoattraction of } \mathrm{M} 2 \text { but not } \\
\text { M1 }\end{array}$ & \\
\hline \multirow[t]{15}{*}{ Li et al. [74] } & \multirow[t]{2}{*}{ HCA-1 } & \multirow{2}{*}{$\begin{array}{l}\text { MET-specific inhibition with } \\
\text { tivantinib or capmatinib }\end{array}$} & Decreased proliferation & \multirow{15}{*}{$\begin{array}{l}\text { Immunomodulation: reduced MET } \\
\text { signaling increases tumor expression of } \\
\text { PD-L1, which inactivates T cells and } \\
\text { prevents immune system-mediated } \\
\text { destruction of HCC cells }\end{array}$} \\
\hline & & & Increased PD-L1 expression & \\
\hline & \multirow[t]{2}{*}{ Нер3В } & $\begin{array}{l}\text { MET-specific inhibition with } \\
\text { tivantinib or capmatinib }\end{array}$ & Increased PD-L1 expression & \\
\hline & & MET knockdown & Increased PD-L1 expression & \\
\hline & $\begin{array}{l}\text { SK-HEP-1, HA59T, HA22T, PLC, WRL68, Huh7, } \\
\text { Mahlavu, and Tong }\end{array}$ & MET knockdown & Increased PD-L1 expression & \\
\hline & HCA-1 xenograft immunodeficient mice & $\begin{array}{l}\text { MET-specific inhibition with } \\
\text { tivantinib or capmatinib }\end{array}$ & Decreased tumor progression & \\
\hline & \multirow[t]{6}{*}{ HCA-1 xenograft immunocompetent mice } & \multirow[t]{3}{*}{$\begin{array}{l}\text { MET-specific inhibition with } \\
\text { tivantinib or capmatinib }\end{array}$} & No change in tumor progression & \\
\hline & & & Increased tumor PD-L1 expression & \\
\hline & & & $\begin{array}{l}\text { Decreased tumor T-cell (CD8+) } \\
\text { activity }\end{array}$ & \\
\hline & & \multirow[t]{3}{*}{$\begin{array}{l}\text { MET-specific inhibition with } \\
\text { capmatinib plus an anti-PD-1 }\end{array}$} & Decreased tumor growth & \\
\hline & & & Increased survival & \\
\hline & & & $\begin{array}{l}\text { Increased tumor T-cell (CD8+) } \\
\text { activity }\end{array}$ & \\
\hline & \multirow[t]{3}{*}{ Hep1-6xenograft immunocompetent mice } & \multirow[t]{3}{*}{$\begin{array}{l}\text { MET-specific inhibition with } \\
\text { tivantinib plus an anti-PD-1 }\end{array}$} & Decreased tumor growth & \\
\hline & & & Increased survival & \\
\hline & & & $\begin{array}{l}\text { Increased tumor T-cell (CD8+) } \\
\text { activity }\end{array}$ & \\
\hline
\end{tabular}

ANGPTL1, angiopoietin-like protein 1; CXCL5, C-X-C motif chemokine 5; EGR1, early growth response protein 1; EMT, epithelial-to-mesenchymal transition; GAS6, growth arrest-specific 6; HCC, hepatocellular carcinoma; HGF, hepatocyte growth factor; $\mathrm{IC}_{50}$, half maximal inhibitory concentration; MET, mesenchymal-to-epithelial transition; MKI, multikinase inhibitor; MMP9, matrix metalloproteinase 9; PD-1, programmed cell death protein 1; PD-L1, programmed cell death ligand 1; R428, investigational TKI that targets AXL; RTK, receptor tyrosine kinase; SU11274, investigational inhibitor of c-MET; TP0903 is an investigational inhibitor that targets AXL; TGF- $\beta$, transforming growth factor beta. 


\section{AXL in the Regulation of HCC Progression}

Most HCC cases occur in patients with liver cirrhosis caused by infection with hepatitis $\mathrm{B}$ or $\mathrm{C}$, nonalcoholic steatohepatitis, excessive alcohol use, or metabolic disorders [25]. Chronic inflammation caused by these conditions leads to changes in the extracellular matrix that promote liver fibrosis and tumorigenesis [26]. Increased levels of soluble AXL in serum have been identified as a biomarker for cirrhosis, fibrosis, and early HCC $[27,28]$. In addition, elevated AXL expression in tumor samples from cohorts of patients with $\mathrm{HCC}$ has been associated with cirrhosis, microvascular invasion, increased tumor size and number, advanced tumor stage, and higher mortality and rate of recurrence $[29,30]$. AXL expression is, therefore, highly correlated with HCC progression and outcomes. Several studies have explored the effects of targeted manipulation of AXL signaling on HCC cell properties (Table 1) and associated downstream molecular pathways (Fig. 1).

\section{$A X L$ and TGF- $\beta$ Signaling}

Transforming growth factor (TGF)- $\beta$ is a profibrogenic cytokine that is activated and released from various cell types during acute and chronic liver damage [31] and is thought to play a key role in the progression of liver cirrhosis to HCC [32]. However, the role of TGF- $\beta$ in HCC is biphasic: it exhibits antioncogenic activities in normal hepatocytes to suppress HCC development, while also triggering pro-oncogenic activities at later stages of HCC $[33,34]$. Antioncogenic processes regulated by TGF- $\beta$ include inhibition of cell-cycle progression, induction of apoptosis, and maintenance of tissue architecture [34], while pro-oncogenic processes include disruption of cell adhesion, induction of migration and invasion, immune suppression, and angiogenesis [34]. TGF- $\beta$ also regulates the epithelial-to-mesenchymal transition (EMT) of malignant hepatocytes [35], which is associated with enhanced migration and increased local HCC cell invasion and intrahepatic metastasis [36].

Studies have shown that AXL plays a key role in regulating the switching of TGF- $\beta$ signaling from an antito a pro-oncogenic target gene regulator. In the recent study by Reichl et al. [37], AXL was found to be upregulated in EMT-transformed mesenchymal HCC cells compared with in epithelial HCC cells. Furthermore, knockdown of AXL inhibited invasion and trans-endothelial migration of mesenchymal HCC cells, while overexpression of AXL or stimulation with its ligand, growth arrest-specific 6 (GAS6), increased these effects (Table 1) [37]. In poorly migrating epithelial HCC cells

AXL and MET in Hepatocellular

Carcinoma that lack AXL expression, overexpression of AXL increased tumor growth and enhanced metastatic nodule formation in xenograft mice [37]. AXL knockdown was also strongly associated with increased susceptibility of mesenchymal HCC cells to TGF- $\beta$-induced cell death, while stimulation of AXL with its ligand GAS6 increased the expression of prometastatic TGF- $\beta$ target genes and enhanced TGF- $\beta 1$ secretion. These effects were dependent on aberrant phosphorylation of the Smad3 linker (Smad3L) region by AXL, 14-3-3 , and cJUN N-terminal kinase (JNK) signaling (Fig. 1). These findings imply a role for enhanced AXL activity in mediating resistance to antioncogenic processes promoted by TGF- $\beta$ [37]. Consistent with these data, high AXL and $14-3-3 \zeta$ expression in samples from patients with HCC correlated with elevated vessel invasion, higher risk of tumor recurrence after liver transplantation, and shorter survival times [37].

Another study assessed the effects of duration of TGF- $\beta$ exposure on the mesenchymal-like HCC cell functions mediated by the TGF- $\beta$ signaling pathway. Similar reductions in migration behavior of approximately $22 \%$ were observed in the mesenchymal-like HCC cell lines SNU-449 and HLF after short-term (24h) incubation with TGF- $\beta$, while long-term incubation (>10 days) with TGF- $\beta$ increased migration by $50 \%$ in HLF cells and decreased migration by $50 \%$ in SNU-449 cells. In patients with HCC, the synergy of TGF- $\beta$ and AXL was found to induce $\mathrm{C}-\mathrm{X}-\mathrm{C}$ motif chemokine 5 (CXCL5) signaling, which resulted in neutrophil infiltration in HCC tissue (see section on Immunomodulation by AXL and MET in HCC for more details) [38].

\section{AXL Regulation of PI3K/AKT and ERK/MAPK \\ Pathways}

In a recent study by Pinato et al. [24], AXL overexpression was observed in 13 of 28 immortalized HCC cell lines and was correlated with known markers of EMT, specifically Vimentin, the EMT marker-protein Slug, and E-cadherin. The correlation of AXL overexpression with markers of EMT was further confirmed in several cancer-cell databases, as well as by the Western blot analysis of the 2 cell lines (SK-HEP-1 and SNU-449) with the highest level of AXL expression [24]. AXL was also found to be overexpressed in liver samples from patients with primary and metastatic HCC compared with those who had cirrhotic or normal livers [24]. Inhibition of AXL in the mesenchymal, AXL-overexpressing cell line SK-HEP-1 was found to inhibit growth and to induce changes consistent with engagement of apoptosis, reduced metabolism, and dis- 
Fig. 1. AXL- (a) and MET-regulated pathways (b) and phenotypic effects in HCC. Numbers in square brackets are references. Superscript letters refer to HCC cell lines used to obtain data (see KEY). Continuous (nondashed) lines indicate experimentally confirmed interactions, while dashed lines indicate correlated effects. All effects depicted were a result of AXL or MET simulation and/or activation and are classified as being most relevant to progression (black text), sorafenib resistance (red text), or immunomodulation (green text). AKT, protein kinase B; CXCL5, C-X-C motif chemokine 5; CYR61, cysteine-rich angiogenic inducer 61; EGR1, early growth response protein 1;ERK, extracellular signal-regulated kinases; F-FDG, fluorodeoxyglucose; GAS6, growth arrest-specific 6; GSK3B, glycogen synthase kinase 3 beta; HGF, hepatic growth factor; JNK, c-JUN N-terminal kinase; MAPK, mitogen-activated protein kinase; MET, mesenchymal-to-epithelial transition; MMP9, matrix metalloproteinase 9; PAK1, p21-activated kinase 1; PAI1, plasminogen-activator inhibitor-1; PD-L1, programmed death ligand 1; PI3K, phosphatidylinositol-3-kinase; Smad3L, Smad3 linker; soraf., sorafenib; TGF- $\beta$, transforming growth factor beta; TRAF6, tumor necrosis factor receptor-associated factor 6 .



(Figure continued on next page.) 


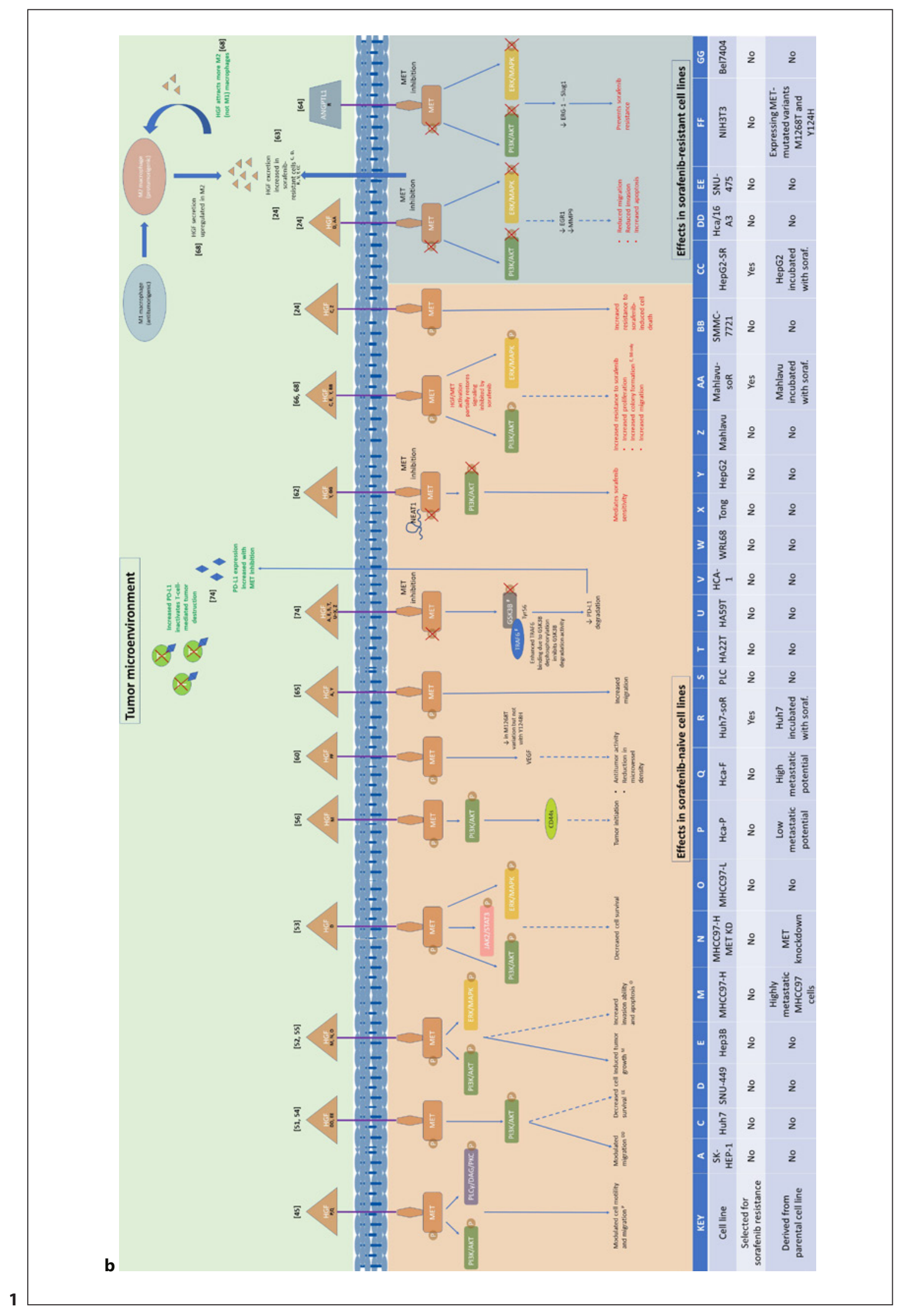


ruption of colony formation (Table 1) [24]. Examination of the effects of AXL inhibition on the phosphatidylinositol-3-kinase (PI3K)/protein kinase B (AKT) pathway in this cell line revealed dose-dependent dephosphorylation of AKT, but no effect on the extracellular signal-regulated kinase (ERK)/mitogen-activated protein kinase (MAPK) pathway [24]. GAS6/AXL activation of PI3K/AKT (but not ERK/MAPK) signaling was also observed by Reichl et al. [37], albeit via different phosphorylation sites (Fig. 1).

AXL has also been shown to activate the PI3K/AKT pathway to stimulate p21-activated kinase-1 (PAK1) activity and cell invasion in HCC cells [39]. Investigation of this pathway identified increased AXL expression in MHCC97-H cells, which have a higher metastatic potential than MHCC97-C cells [39]. Downregulation of AXL in MHCC97-H cells was found to inhibit the PI3K/AKTPAK1 pathway and the invasion ability of these cells in vitro, as well as the tumor formation in vivo (Table 1) [39]. The same study also found that AXL expression correlated with differentiation, lymph node metastasis, and clinical stage in patients with HCC [39].

In another study, the invasion-promoting activity of HA22T cells, which have intrinsically high AXL activity, was found to be stimulated by GAS6 (Table 1), and this activity was dependent on ERK/MAPK upregulation of Slug (Fig. 1) [40]. GAS6 also activated the PI3K/AKT pathway, but this was not required for Slug upregulation [40]. Taken together, current evidence indicates that AXL regulates mechanisms of HCC progression via both PI3K/ AKT and ERK/MAPK signaling, although their relative importance and mode of activation appear to vary, possibly reflecting methodological differences in the studies, such as the use of different HCC cell lines (Fig. 1) [40].

\section{AXL Regulation of CYR61}

CCN proteins, including cysteine-rich angiogenic inducer 61 (CYR61), have been proposed as core regulatory proteins in the TME [41]. CYR61, which encodes an extracellular matrix protein also secreted by hepatic stellate cells, has been implicated in HCC progression [42]. In the mouse HCC cell line Hca-F, which has high metastatic potential, downregulation of AXL expression has been shown to attenuate proliferation, migration, and invasion in vitro, and to inhibit metastasis to peripheral lymph nodes in vivo (Table 1) [43]. Stimulation of AXL by GAS6 in this cell line was predominantly associated with reduced levels of CYR61 [43]. The effect of AXL on CYR61 was also highlighted by Lechertier et al. [44] who demonstrated that the GAS6-AXL-AKT pathway controls CYR61.

\section{MET in the Regulation of HCC Progression}

Hepatocyte growth factor (HGF) is a key regulator of cell growth and migration; the transmembrane protein, MET, acts as the HGF receptor [45]. DNA extracted from surgically resected human HCC has demonstrated the amplification of $M E T$ compared with normal reference DNA (magnitude 3.8) [46]. Assays in HCC cell lines have shown that VEGF signaling inhibition leads to hypoxia, hypoxia-inducible factor-1a nuclear accumulation, and elevated total MET expression [47]. Activation of the HGF/MET pathway has been shown to promote cell migration and invasion in HCC cells [48]. The finding that MET protein expression is increased in the cytoplasm of HCC cells of the highest histological grade compared with those of a lower grade or normal liver tissue indicates that it may be a late event in hepatocarcinogenesis [49]. Furthermore, one recent study describes an increase in HGF immediately following liver resection, suggesting that HGF is a key factor in postsurgical changes to the TME [50].

\section{MET Regulation of PI3K/AKT, PLC $\gamma / D A G / P K C$, and} MAPK/ERK Signaling

Following MET activation, different tyrosine residues are phosphorylated, leading to the activation of the PI3K/ AKT and PLC $\gamma / D A G / P K C$ signaling pathways in mouse hepatoma ascites cell lines (Hca-P, low metastatic potential, and Hca-F, high metastatic potential). PI3K/AKT signaling pathway activity was greater in cells with low metastatic potential than those with high metastatic potential; furthermore, HGF modulated cell motility and migration through the PI3K/AKT pathway in cells with low metastatic potential. Conversely, PLC $\gamma / \mathrm{DAG} / \mathrm{PKC}$ activity was greater in cells with high metastatic potential than those with low metastatic potential; furthermore, HGF was shown to modulate cell motility and migration through the PLC $\gamma / D A G / P K C$ pathway in cells with high metastatic potential [45].

Several studies have demonstrated that downregulation of MET results in downregulation of the downstream targets. When investigating gangliosides in murine hepatoma cells, downregulation of the tyrosine phosphorylation of MET was accompanied by downregulation of the PI3K/AKT signaling pathway and modulation of cell migration in mouse hepatic cell cancer lines (Hca/16A3; high ganglioside GM3 expression) [51]. In addition, cells with decreased MET expression (MET knockdown cell line MHCC97-H MET KD) had significantly decreased the expression of the downstream targets phospho-AKT 
and phospho-ERK compared with control cells (MET + cell line MHCC97-H) [52]. A more recent investigation into MET-induced transition to a hybrid epithelial/mesenchymal phenotype (a fluidic state between the 2 phenotypes, which may be important in tumor metastasis) in HCC cells demonstrated a decrease in downstream AKT, MAPK, and STAT3 signaling pathways when MET was suppressed [53].

Conversely, transient overexpression of MET in human HCC cells (SNU475 and PLC/PRF/5, both with low MET expression) resulted in increased phospho-MET and phospho-ERK1/2 expression; in addition, keratin 19 expression was increased at the mRNA and protein levels [54]. Furthermore, a recent study in HCC cells with high MET expression (MHCC97-L) showed that treatment with HGF increased the phosphorylation of MET and downstream mediators AKT and ERK, suggesting that HGF/MET activates the downstream pathways PI3K/ $\mathrm{AKT}$ and the MAPK/ERK in these cells [55].

Other studies have investigated MET and AKT signaling in further downstream pathways. One study suggested that MET and PI3K/AKT signaling regulates CD44s (standard form) to promote a mesenchymal and tumorinitiating stem-like cells phenotype in human HCC cells (MHCC97-H) [56]. In addition, an in vivo study demonstrated that development of HCC tumors was rapidly induced in mice that coactivated both MET and AKT. These tumors exhibited activation of the AKT/mTOR and Ras/ MAPK cascades [57].

\section{MET and $\beta$-Catenin Signaling}

Mutations in the gene for $\beta$-catenin (which plays a role in the Wnt signaling pathway) have been detected in 20$40 \%$ of patients with HCC [58]. In an in vivo investigation based on hepatocyte-specific $\beta$-catenin knockout mice, the $\beta$-catenin-deficient livers exhibited tumor-promoting stromal changes that exacerbated HCC development driven by a mutated version of $\beta$-catenin in cooperation with MET [58].

\section{MET Regulation of MLL/ETS2}

Mixed-lineage leukemia (MLL) is an epigenetic transcriptional regulator that has been identified as an important factor in cell fate, stem cell, and cell cycle decisions [59]. Takeda et al. [59] investigated the downstream signaling pathway MLL-ETS2 in murine models of HCC. They found that mice with noncleavable mutations in endogenous $M L L$ demonstrated impaired outgrowth of the cranial nerve XII (a process regulated by HGF/MET). They also observed that HGF/MET induced the activity of MLL and ETS2, which directly activated transcription of $M M P 1$ and MMP3 (involved in HCC cell invasion) [59].

\section{MET Regulation of VEGF}

Inhibition of MET in xenograft liver tumor models of mouse fibroblast cells (NIH3T3), which express activating MET-mutated variants (M1268T and $\mathrm{Y} 1248 \mathrm{H}$; constitutive kinase activity), resulted in a reduction in VEGF levels in the NIH3T3 containing the M1268T variation, but not the $\mathrm{Y} 1248 \mathrm{H}$ variation. Inhibition of MET also revealed antitumor activity and a reduction in microvessel density in M1268T-derived intrahepatic tumors [60].

\section{AXL and MET in Sorafenib Resistance}

Recent investigation, by Pinato et al. [24], of sorafenibresistant clones derived from Huh7 (Huh7-soR; predominantly epithelial and AXL-negative) and SK-HEP-1 (SKHEP-SR; predominantly mesenchymal and AXL-overexpressing) HCC cells (generated by growing in increasing concentrations of sorafenib up to $10 \mu \mathrm{M}$, with surviving cells maintained at $6 \mu \mathrm{M}$ after 6 months) revealed increased migration and invasion capacity compared with their sorafenib-naive counterparts. Antibody arrays showed increased phosphorylation of several RTKs in both sorafenib-resistant cell lines, including AXL in the SK-HEP-SR cells [24]. Both sorafenib-resistant cell lines demonstrated increased phosphorylation of AKT, SRC, and EHP receptor B4 (EPHB4) compared with their sorafenib-naive equivalents [24]. Expression analysis showed significant increases in AXL and MET phosphorylation in sorafenib-resistant SK-HEP-1-SR cells, while various EMT marker proteins had increased expression in sorafenib-resistant Huh7-soR cells [24]. AXL inhibition in sorafenib-resistant SK-HEP-1-SR cells was found to modulate cell motility and invasion, and to increase sensitivity to sorafenib-mediated apoptosis and antiproliferative effects (Table 1) [24]. Activation of AXL has also been observed with development of resistance to sorafenib (defined by a lack of tumor suppression effect with sorafenib after 2 rounds of treatment) in HCC cells in at least one other recent study [61].

Firtina Karagonlar et al. [23] investigated the potential role of HGF/MET signaling in resistance to sorafenib using sorafenib-resistant clones (obtained by exposing cell lines to increasing concentrations of sorafenib, becoming "sorafenib resistant" over 3-5 months) derived from the HCC cell lines Mahlavu (Mahlavu-soR; predominantly 
mesenchymal and MET-positive) and Huh7 (Huh7-soR; predominantly epithelial and MET-negative). Similar to the Pinato et al. [24] study, sorafenib-resistant HCC cells displayed increased migration and invasion abilities versus their sorafenib-naive counterparts, and sorafenib-resistant Huh7-soR cells had increased markers of EMT [23]. However, in contrast to the sorafenib-resistant mesenchymal cell line (SK-HEP-1-SR) used by Pinato et al. [24], in which EMT markers were not altered, markers of EMT were further increased in sorafenib-resistant Mahlavu-soR cells [23]. Both sorafenib-resistant cell lines had higher HGF expression and secretion, and sorafenib-mediated cell death could be attenuated in the parental, sorafenib-naive versions of these cell lines by incubation with HGF [23]. In addition, both sorafenib-resistant cell lines had drastically elevated MET phosphorylation (in contrast with the findings from reference [24]), and MET inhibition partially reversed the increases in migration and invasion associated with sorafenib resistance (Table 1) [23]. Upregulated phosphorylation of AKT and ERK, and decreased expression of early growth response protein 1 (EGR1) and matrix metalloproteinase 9 (MMP9) were observed in parallel with MET activation in both sorafenib-resistant cell lines and these effects were abrogated by MET inhibition (Fig. 1) [23].

MET and the downstream AKT pathway are involved in sorafenib resistance in HCC cells. Cell viability assays demonstrated that suppression of the MET-AKT pathways using long noncoding RNA nuclear-enriched abundant transcript 1 (NEAT1) can overcome sorafenib resistance (no definition of sorafenib resistance was published) [62]. Another study used immunohistochemistry and immunoblotting to demonstrate that sorafenib-resistant Huh7 and HepG2 HCC cells (sorafenib-resistant cells were "established previously," resuscitated, incubated with sorafenib, and continuously cultured in the presence of sorafenib) express higher levels of HGF than parental cells [63]. Exposure to sorafenib resulted in upregulation of phosphorylated MET, AKT, and ERK in sorafenib-resistant and parental HCC cells, with similar results seen with MHCC-7721 and MHCC-3M cells [63].

An in vitro binding assay demonstrated direct binding of angiopoietin-like protein 1 (ANGPTL1) to MET, and inhibition of MET phosphorylation by competing with HGF. ANGPTL1 binding to MET blocked downstream pathways, including AKT/ERK, and prevent sorafenib resistance (cells were treated with increasing doses of sorafenib and the resulting sorafenib-resistant cells were maintained in culture medium containing sorafenib) [64].
Though more related to HCC progression than to the development of sorafenib resistance, it should be noted that another study also found that MET stimulation with HGF in SK-HEP-1 and HepG2 cells enhanced their migration and invasion capacity and that these MET-stimulated effects were inhibited with cabozantinib treatment (Table 1) [65]. In addition, cabozantinib decreased angiogenesis, inhibited proliferation, and promoted apoptosis to a greater extent in a MET phosphorylation-positive HCC xenograft model than in a MET phosphorylationnegative HCC xenograft model, suggesting that at least some of the observed effects of this MKI were due to inhibition of MET [65]. Following on from this work, the same group found that treatment with sorafenib alone inhibited phosphorylation of AKT and ERK1/2 in HCC cells (HepG2 and Huh7), and combination treatment with sorafenib and HGF led to activation of MET and downstream AKT and MAPK [66].

Consistent with the evidence that altered MET signaling plays a significant role in sorafenib resistance, high levels of phosphorylated MET in resected liver specimens from patients with HCC have been associated with resistance to adjuvant sorafenib therapy. For example, in the study by Pinato et al. [24], higher baseline serum levels of soluble AXL in patients with HCC were found to be associated with higher rates of sorafenib discontinuation due to disease progression, and with reduced OS. Furthermore, in a study by Xiang et al. [65], 7 of 12 patients (58.3\%) with sorafenib-resistant HCC were found to have high levels of phosphorylated MET compared with 1 of 17 patients (5.9\%) with sorafenib-sensitive HCC.

In summary, both MET and AXL are key regulators of sorafenib resistance in HCC. Importantly, however, even in the same HCC cell lines (e.g., Huh7), variation may exist in the pathways that are activated to achieve resistance.

\section{Immunomodulation by AXL and MET in HCC}

TAMs are abundant in the TME, where they exist in 2 distinct phenotypic forms, referred to as M1 and M2 [67]. M2 macrophages promote HCC cell proliferation, migration, and colony formation and are generally considered to be protumorigenic, while M1 macrophages do not promote these characteristics and are generally considered to be antitumorigenic $[67,68]$. TAM receptors such as AXL promote macrophage switching from the antitumorigenic M1 phenotype to the protumorigenic M2 phenotype [67]. Increased M2 macrophage numbers due to AXL overexpression may play a role in mediating sorafenib re- 
sistance in HCC. Specifically, M2 macrophages have been shown to promote HCC resistance to sorafenib via secretion of HGF (Table 1), leading to activation of HGF/MET signaling and its downstream effectors ERK/MAPK and PI3K/AKT (Fig. 1) [68]. In addition, HGF was found to attract M2 macrophages, which were also found to be associated with sorafenib-resistant (vs. nonresistant) tumors in mice, providing a potential positive-feedback mechanism for acquired resistance [68]. This may be further compounded by the enhanced HGF secretion observed in some sorafenib-resistant HCC cell lines (Fig. 1) [23]. Taken together, these data indicate the potential for interaction of AXL and MET via TME immune components to promote tumorigenesis and treatment resistance in HCC.

AXL may also regulate neutrophil-mediated, tumorpromoting effects. In patients with HCC, neutrophil infiltration can be mediated by CXCL5 and is an indicator of poor prognosis $[69,70]$. Transcriptome profiling in mesenchymal-like HCC cell lines revealed significant changes in expression of CXCL5 with long-term TGF- $\beta$ treatment, with expression being increased in HLF cells and decreased in SNU-449 cells [38]. Further analysis revealed that TGF- $\beta$-mediated secretion of CXCL 5 was dependent on AXL (Table 1; Fig. 1) [38]. CXCL5 was also found to be expressed exclusively in patients with TGF$\beta$-positive HCC, in whom high levels of AXL and CXCL5 were correlated with advanced disease and shorter OS [38]. Long-term incubation of HCC cells with TGF- $\beta$ has been shown to induce the recruitment of neutrophils via CXCL5 in an AXL/TGF- $\beta$-dependent manner (Fig. 1) [38]. In addition, recruitment of neutrophils into liver tissue in patients with HCC in this study was associated with high levels of AXL and CXCL5 [38]. Neutrophils can have protumorigenic (N2 phenotype) or antitumorigenic (N1 phenotype) effects depending on the TME [71, 72]. Interestingly, cytokines such as TGF- $\beta$, for which secretion may be enhanced with AXL stimulation [37], can shift neutrophils toward a protumorigenic N2 phenotype [73]. AXL may, therefore, play a role in both neutrophil recruitment and induction toward a protumorigenic neutrophil phenotype in HCC.

Perhaps of most interest from the perspective of future approaches to HCC treatment is that increased MET activation has been found to reduce expression of the immune checkpoint protein ligand "programmed death ligand 1" (PD-L1) in liver cancer cell lines [74]. Conversely, specific inhibition of MET with capmatinib and tivantinib was found to increase PD-L1 expression and to inactivate cocultured T cells, as well as to decrease the an-

AXL and MET in Hepatocellular

Carcinoma titumor activity of T cells in mice (Table 1) [74]. When MET inhibition was combined with programmed cell death protein (PD-1) inhibition in mice, there was an additive reduction in HCC cell growth [74], suggesting the potential for synergistic anti-HCC effects with the combination of MET and immune checkpoint inhibition.

\section{Discussion}

The role of AXL in HCC has been investigated in numerous HCC models, predominantly in relation to disease progression (Fig. 1). Available literature supports a key role for AXL overactivation in increased HCC cell growth and metabolism, enhanced colony-forming ability, increased invasion and migration capacity, and resistance to TGF- $\beta$-induced cell death. Studies in sorafenibnaive HCC cells reveal AXL signaling via phosphorylation of PI3K/AKT, ERK/MAPK, JNK, and PAK1. AXL stimulation has also been shown to increase the expression of TGF- $\beta$ target proteins (PAL1, MMP9, and Snail) and the transcription factor Slug, and to decrease the expression of CYR61 (Fig. 1). Increased invasion capacity due to AXL stimulation in HA22T cells was dependent on upregulation of Slug via ERK/MAPK signaling.

Signaling by MET in HCC cells has been investigated in relation to both disease progression and sorafenib resistance (Fig. 1). In terms of disease progression, recently published literature supports the role of MET in modulating HCC cell motility and migration, metastases, invasion, and angiogenesis. MET activation was found to partially restore sorafenib-inhibited PI3/AKT and ERK/MAPK signaling (Fig. 1). Stimulation of MET has been shown to increase resistance to sorafenib in sorafenib-naive HCC cells, while MET inhibition has been shown to reduce the tumorigenic properties of sorafenib-resistant HCC cells. Sorafenib-resistant HCC cells also overexpress HGF, which simulates MET and may attract HGF-secreting M2 macrophages to further increase MET activation and provide a feedback-back mechanism for acquired resistance. Signaling via the PI3/AKT and ERK/MAPK pathways was abrogated by MET inhibition in sorafenib-resistant cells and was associated with downregulation of EGR1 and MMP9. These findings are consistent with clinical trial data for cabozantinib, a potent MET inhibitor, that show improved OS and PFS in patients with HCC who have received prior sorafenib treatment $[3,75]$. However, studies also show that AXL inhibition increases sorafenib susceptibility in sorafenib-naive and sorafenib-resistant HCC cells and reduces protumorigenic properties (prolifera- 
tion, metastatic capacity, and resistance to cell death) in sorafenib-resistant HCC cells. Further, cabozantinib also has potent inhibitory activity against AXL, suggesting that its efficacy against sorafenib-resistant HCC cells may be due to its MKI activity, rather than inhibition of a single RTK receptor.

In addition to contributing to HCC progression and resistance phenotypes, studies in various non-HCC cancers indicate that AXL signaling in the TME has a suppressive effect on both adaptive and innate immune system responses to tumor cells [76-80]. Conversely, prevention of AXL signaling may make the TME more immunopermissive, favoring tumor destruction [76-80]. A key exception appears to be PD-L1 expression, which is increased with AXL inhibition and acts to suppress adaptive immunity in the TME [76]. AXL and TAM inhibitors have displayed potent synergistic antitumor activity when used in combination with PD-1 checkpoint inhibitors in vivo $[76,79]$. PD-1 checkpoint inhibitors may thus remove a key roadblock to achieving the full benefits of AXL inhibition in terms of immune-mediated destruction of tumor cells. MET inhibition has also been shown to increase PD-L1 expression, specifically in HCC cells, and to have synergistic antitumor activity with checkpoint inhibitors [74]. Increased PD-L1 expression in response to MET inhibition was dependent on dephosphorylation of glycogen synthase kinase 3 beta (GSK3B), leading to reduced degradation of PD-L1 by this molecule due to enhanced binding to tumor necrosis factor receptor-associated factor 6 (TRAF6). Based on the above findings, Slug, GSK3B, and TRAF6 may be potential targets of future drug development in HCC. Unfortunately, all other molecular changes downstream of AXL or MET manipulation described in these studies were merely associated with protumorigenic effects in HCC cells (Fig. 1). We only identified a few studies that investigated the effects of AXL or MET signaling on immunomodulation of the TME in HCC; additional HCC-specific studies are needed in this area to establish the relevance of these molecules to HCC pathology. Meanwhile, it is reassuring that the synergistic antitumor effects of AXL, MET, and immune checkpoint inhibition observed in HCC studies mirror those observed in preclinical studies of cabozantinib combined with immune checkpoint inhibitors in prostate cancer and breast cancer $[81,82]$, and in castration-resistant prostate cancer, renal cell carcinoma, nonsmall cell lung cancer, urothelial carcinoma, and HCC (limited data) in clinical studies [83-88].

Preclinical studies in non-HCC cancers suggest that cabozantinib may exert some of its antitumor effects by enhancing immune responses to cancer cells [89, 90]. Some of these effects, such as increasing the ratio of immune permissive CD4 and CD8 cells to immune suppressive myeloid-derived repressor cells [89], seem to be consistent with effects also observed with AXL-specific inhibition [79]. Cabozantinib has also been shown to inhibit interleukin-4-stimulated M2-macrophage polarization [90], and TAM receptors are known to affect macrophage populations, promoting switching from the antitumorigenic M1 phenotype to the protumorigenic M2 phenotype [67].

Available information on the effects of cabozantinib on neutrophil recruitment appears inconsistent with the effects of AXL- or MET-specific inhibition. In mice with prostate cancer, eradication of cancer with cabozantinib was associated with enhanced release of neutrophil chemotactic factors and robust neutrophil infiltration [91]. In contrast, both AXL and MET inhibitors have been shown to decrease neutrophil recruitment in cancer cells $[16,38]$, and neutrophil infiltration in these studies was associated with poorer outcomes in patients with cancer $[16,38]$. These apparent contradictions may be a consequence of simultaneous inhibition of multiple RTKs by cabozantinib (e.g., VEGFR2, KIT, RET, FLT3, TIE2, AXL, TYRO3, and MET) versus specific inhibition of AXL or MET. They may also be related to variation in the pathological factors that underlie different cancer types and their evolution over time. For example, TGF- $\beta$ secretion is increased with AXL stimulation in HCC [37] and may shift neutrophils from an antitumorigenic N1 phenotype to a protumorigenic N2 phenotype [73]. Neutrophil infiltration may therefore have positive or negative effects depending on the associated TME. Indeed, MET inhibition has been shown to suppress the acquisition of immunosuppressive properties by neutrophils when recruited to T-cell-inflamed TMEs [16]. These data highlight the importance of using appropriate cancer-type-specific models, and of using targeted inhibition of specific pathways, for the preclinical elucidation of clinically relevant cancer mechanisms.

A search of ClinicalTrials.gov conducted to identify recent and ongoing trials of AXL and/or MET inhibitors in patients with HCC found 26 investigational molecules (21 small molecule inhibitors and 5 monoclonal antibodies) targeting AXL $(n=3)$, MET $(n=20)$, or both $(n=3)$ (online suppl. Table 1). However, only a handful of these molecules (cabozantinib, APL-101, tepotinib, capmatinib [INC280], and sitravatinib) are being investigated in HCC populations (Table 2), and most of the related trials $(11 / 17)$ are evaluations of cabozantinib. It should be not- 


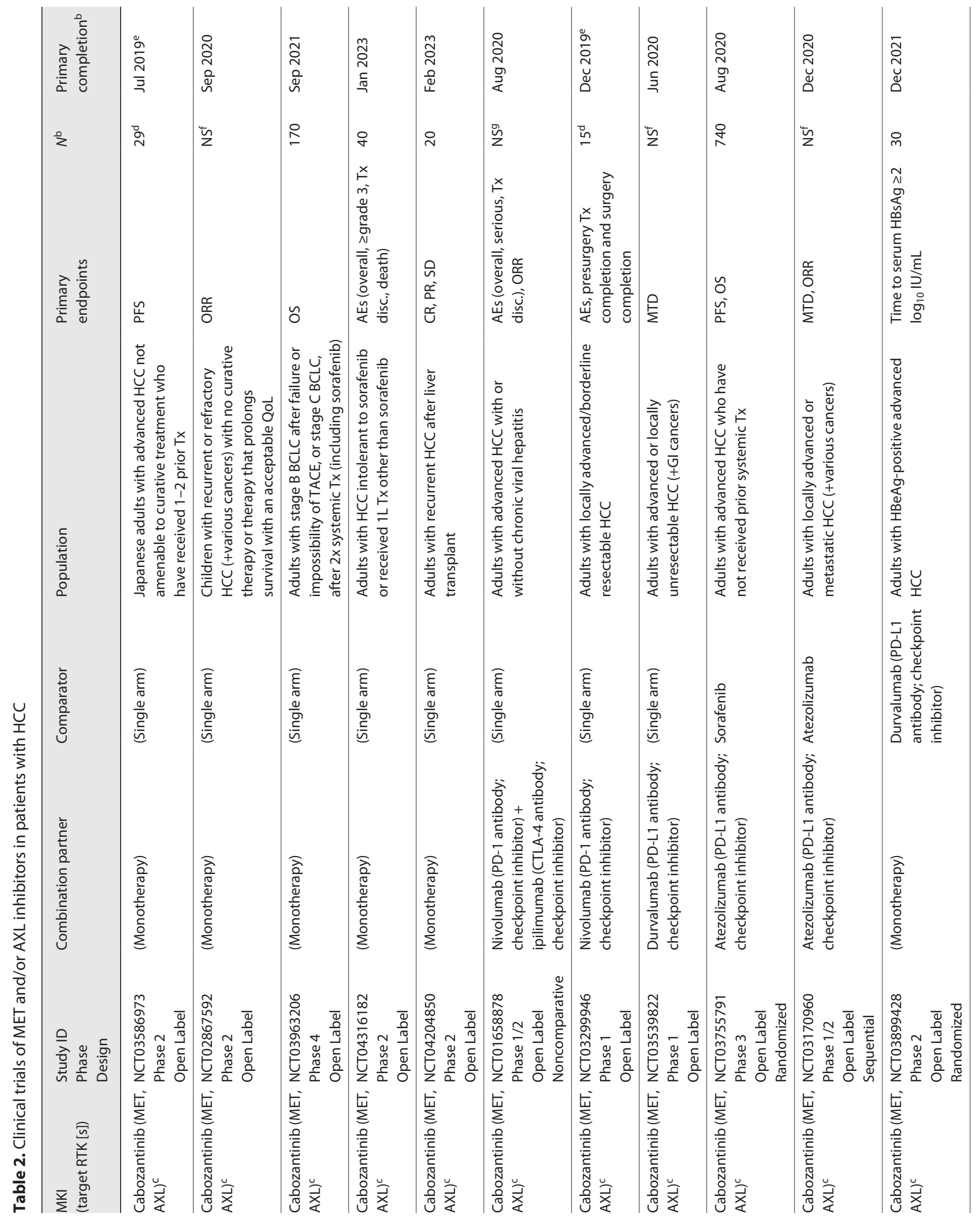




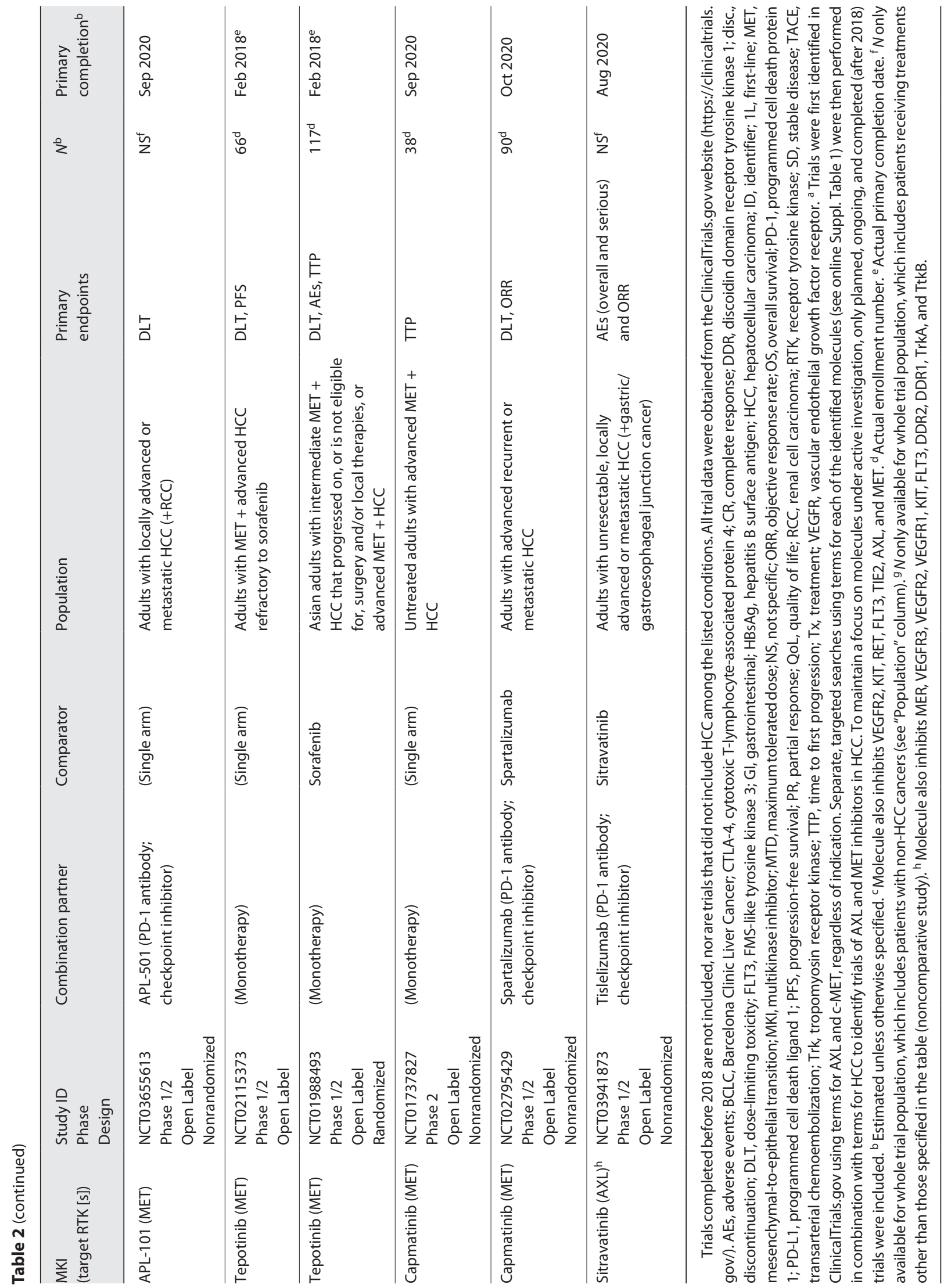


ed that trials were only included if HCC was specifically referred to in the trial population, and so it is likely that some trials that include patients with HCC as part of broader cancer (e.g., solid tumor) populations were missed. Nevertheless, drugs targeting these receptors seem underrepresented in HCC trials.

The lack of MET inhibitors in ongoing clinical trials for HCC may be partly due to the recent failure of some MET-targeting molecules, such as tivantinib, in patients with high-MET-expression HCC following prior treatment with sorafenib [92]. However, recent evidence that increased PD-L1 expression with MET inhibition may stifle the benefits of this approach in HCC highlights the potential for combination approaches involving checkpoint inhibitors. Although not specifically investigated in HCC, evidence of increased PD-L1 expression with AXL inhibitors in other cancers portends similar possible benefits. This reasoning seems to be reflected in the fact that at least $4 \mathrm{MET}$ and/or AXL inhibitors (sitravatinib, cabozantinib, APL-101, and capmatinib [INC280]) are being investigated in combination with checkpoint inhibition in trials of advanced HCC (Table 2). Preliminary reports from the CheckMate040 study of cabozantinib in combination with nivolumab with and without ipilimumab in patients with advanced HCC have shown clinically meaningful responses with an objective response rate of $17 \%$ with the double combination and $26 \%$ for the triple combination [88]. A recent press release described initial, positive results from the COSMIC-312 trial of cabozantinib in combination with atezolizumab versus sorafenib in patients with previously untreated advanced HCC. This study was designed to evaluate multiple primary endpoints, with both PFS and OS designated as 2 distinct primary endpoints. In the analysis of PFS, the combination of cabozantinib plus atezolizumab demonstrated a significant improvement relative to sorafenib (hazard ratio, 0.63 ; 99\% confidence interval, $0.44-0.91 ; p=0.0012$ ). However, the prespecified interim analysis of OS did not reach statistical significance. Full results of COSMIC-312 are anticipated in early 2022 [93]. Interestingly, the importance of AXL and MET as HCC cell markers is also being recognized by exploration of these receptors in trials as targets for antibody-drug conjugate treatment and chimeric antigen receptor $\mathrm{T}$-cell injection therapy (online suppl. Table 1).

Finally, it is worth noting that, despite the majority of available in vitro and in vivo evidence supporting a role for AXL signaling in HCC progression, no trials of molecules with inhibitory activity against AXL were identified that are being investigated in early HCC. This seems to be a gap in the current clinical trial landscape that is worthy of future exploration.

\section{Conclusion}

AXL and MET play key roles in HCC progression, treatment resistance, and immunomodulation, and the continued development of drugs that target these RTKs may be a useful strategy to improve outcomes for patients with HCC.

\section{Acknowledgments}

The authors thank Michael Molloy-Bland (PhD) of Oxford PharmaGenesis Ltd. for providing medical writing support, which was sponsored by Ipsen, Abingdon, UK, in accordance with Good Publication Practice 3 (GPP3) guidelines.

\section{Statement of Ethics}

An ethics statement is not applicable because this study is based exclusively on published literature.

\section{Conflict of Interest Statement}

Y.H.H. has received research grants from Gilead Sciences and Bristol Myers Squibb, and honoraria from Abbvie, Gilead Sciences, Bristol Myers Squibb, Ono Pharmaceutical, Merck Sharp \& Dohme, Eisai, Eli Lilly, Ipsen, and Roche, and has served in an advisory role for Abbvie, Gilead Sciences, Bristol Myers Squibb, Ono Pharmaceutical, Eisai, Eli Lilly, Ipsen, Merck Sharp \& Dohme, and Roche. C.H. has received research grants from Bristol Myers Squibb/Ono Pharmaceutical, Ipsen, and Roche, and fees from the following pharmaceutical companies: AstraZeneca, Bayer, Bristol Myers Squibb/Ono Pharmaceutical, Eisai, Eli Lilly, Ipsen, Merck Serono, MSD, Novartis, PharmaEngine, Roche, and TTY Biopharm. C.-H.H. has received a research grant from Merck Sharp \& Dohme and Ipsen, and honoraria from Bristol Myers Squibb, Ono Pharmaceutical, Merck Sharp \& Dohme, and Roche, and has served in an advisory role for Ono Pharmaceutical, Merck Sharp \& Dohme, Eli Lilly, Roche, Genentech, Bristol Myers Squibb, and Merck Serono.

\section{Funding Sources}

The development of this manuscript and open access fee were funded by Ipsen. The sponsor was not involved in development of the content, selection, and interpretation of the included data, and overall conclusion of the review; the sponsor reviewed the article for scientific accuracy only. 


\section{Author Contributions}

Yi-Hsiang Huang, Chih-Hung Hsu, Shi-Ming Lin, and Chiun Hsu devised the conceptual ideas and methodology, reviewed and edited the manuscript, involved in data visualization, and supervised the findings of the work.

\section{Data Availability Statement}

All data generated or analyzed during this study are included in this article and its online supplementary material files. Further enquiries can be directed to the corresponding author.

\section{References}

1 Forner A, Reig M, Bruix J. Hepatocellular carcinoma. Lancet. 2018 Mar 31;391(10127): 1301-14.

2 Llovet JM, Montal R, Sia D, Finn RS. Molecular therapies and precision medicine for hepatocellular carcinoma. Nat Rev Clin Oncol. 2018 Oct;15(10):599-616.

3 Abou-Alfa GK, Meyer T, Cheng AL, ElKhoueiry AB, Rimassa L, Ryoo BY, et al. Cabozantinib in patients with advanced and progressing hepatocellular carcinoma. N Engl J Med. 2018 Jul 5;379(1):54-63.

4 Llovet JM, Ricci S, Mazzaferro V, Hilgard P, Gane E, Blanc JF, et al. Sorafenib in advanced hepatocellular carcinoma. N Engl J Med. 2008 Jul 24;359(4):378-90.

5 Cheng AL, Kang YK, Chen Z, Tsao CJ, Qin S, Kim JS, et al. Efficacy and safety of sorafenib in patients in the Asia-Pacific region with advanced hepatocellular carcinoma: a phase III randomised, double-blind, placebo-controlled trial. Lancet Oncol. 2009 Jan;10(1):25-34.

6 Ray EM, Sanoff HK. Optimal therapy for patients with hepatocellular carcinoma and resistance or intolerance to sorafenib: challenges and solutions. J Hepatocell Carcinoma. 2017;4:131-8

7 Yamaoka T, Kusumoto S, Ando K, Ohba M, Ohmori T. Receptor tyrosine kinase-targeted cancer therapy. Int J Mol Sci. 2018 Nov 6; 19(11):3491.

8 Du Z, Lovly CM. Mechanisms of receptor tyrosine kinase activation in cancer. Mol Cancer. 2018 Feb 19;17(1):58.

9 Correll PH, Morrison AC, Lutz MA. Receptor tyrosine kinases and the regulation of macrophage activation. J Leukoc Biol. 2004 May; 75(5):731-7.

10 Vargas-Leal V, Bruno R, Derfuss T, Krumbholz M, Hohlfeld R, Meinl E. Expression and function of glial cell line-derived neurotrophic factor family ligands and their receptors on human immune cells. J Immunol. 2005 Aug 15;175(4):2301-8.

11 Nag K, Chaudhary A. Mediators of tyrosine phosphorylation in innate immunity: from host defense to inflammation onto oncogenesis. Curr Signal Transduct Ther. 2009 May; 4(2):76-81.

12 Yang J, Yan J, Liu B. Targeting VEGF/VEGFR to modulate antitumor immunity. Front Immunol. 2018;9:978.

13 Mishra A, Wang J, Shiozawa Y, McGee S, Kim J, Jung Y, et al. Hypoxia stabilizes GAS6/Axl signaling in metastatic prostate cancer. $\mathrm{Mol}$ Cancer Res. 2012 Jun;10(6):703-12.
14 Schoumacher M, Burbridge M. Key roles of AXL and MER receptor tyrosine kinases in resistance to multiple anticancer therapies. Curr Oncol Rep. 2017 Mar;19(3):19.

15 Akalu YT, Rothlin CV, Ghosh S. TAM receptor tyrosine kinases as emerging targets of innate immune checkpoint blockade for cancer therapy. Immunol Rev. 2017 Mar;276(1): $165-77$.

16 Glodde N, Bald T, van den Boorn-Konijnenberg D, Nakamura K, O'Donnell JS, Szczepanski S, et al. Reactive neutrophil responses dependent on the receptor tyrosine kinase cMET limit cancer immunotherapy. Immunity. 2017 Oct 17;47(4):789-802.e9.

17 Cabometyx US prescribing information. 2019.

18 Agency EM. Cabometyx SmPC. 2020.

19 Yakes FM, Chen J, Tan J, Yamaguchi K, Shi Y, Yu P, et al. Cabozantinib (XL184), a novel MET and VEGFR2 inhibitor, simultaneously suppresses metastasis, angiogenesis, and tumor growth. Mol Cancer Ther. 2011 Dec; 10(12):2298-308.

20 Feneyrolles C, Spenlinhauer A, Guiet L, Fauvel B, Dayde-Cazals B, Warnault P, et al. Axl kinase as a key target for oncology: focus on small molecule inhibitors. Mol Cancer Ther. 2014 Sep;13(9):2141-8.

21 Ikeda S, Schwaederle M, Mohindra M, Fontes Jardim DL, Kurzrock R. MET alterations detected in blood-derived circulating tumor DNA correlate with bone metastases and poor prognosis. J Hematol Oncol. 2018 Jun 4; 11(1):76.

22 Zhang Y, Xia M, Jin K, Wang S, Wei H, Fan $\mathrm{C}$, et al. Function of the c-Met receptor tyrosine kinase in carcinogenesis and associated therapeutic opportunities. Mol Cancer. 2018 Feb 19;17(1):45.

23 Firtina Karagonlar Z, Koc D, Iscan E, Erdal E, Atabey N. Elevated hepatocyte growth factor expression as an autocrine c-Met activation mechanism in acquired resistance to sorafenib in hepatocellular carcinoma cells. Cancer Sci. 2016 Apr;107(4):407-16.

24 Pinato DJ, Brown MW, Trousil S, Aboagye $\mathrm{EO}$, Beaumont J, Zhang $\mathrm{H}$, et al. Integrated analysis of multiple receptor tyrosine kinases identifies Axl as a therapeutic target and mediator of resistance to sorafenib in hepatocellular carcinoma. Br J Cancer. 2019 Mar; 120(5):512-21.

25 Llovet JM, Zucman-Rossi J, Pikarsky E, Sangro B, Schwartz M, Sherman M, et al. Hepatocellular carcinoma. Nat Rev Dis Primers. 2016 Apr 14;2:16018.
26 Hernandez-Gea V, Toffanin S, Friedman SL, Llovet JM. Role of the microenvironment in the pathogenesis and treatment of hepatocellular carcinoma. Gastroenterology. 2013 Mar; 144(3):512-27.

27 Dengler M, Staufer K, Huber H, Stauber R, Bantel $\mathrm{H}$, Weiss $\mathrm{KH}$, et al. Soluble Axl is an accurate biomarker of cirrhosis and hepatocellular carcinoma development: results from a large scale multicenter analysis. Oncotarget. 2017 Jul 11;8(28):46234-48.

28 Staufer K, Dengler M, Huber H, Marculescu $\mathrm{R}$, Stauber R, Lackner C, et al. The non-invasive serum biomarker soluble Axl accurately detects advanced liver fibrosis and cirrhosis. Cell Death Dis. 2017 Oct 26;8(10):e3135.

29 Liu J, Wang K, Yan Z, Xia Y, Li J, Shi L, et al. Axl expression stratifies patients with poor prognosis after hepatectomy for hepatocellular carcinoma. PLoS One. 2016;11(5):e0154767.

30 Hsu CC, Hsieh PM, Chen YS, Lo GH, Lin HY, Dai CY, et al. Axl and autophagy LC3 expression in tumors is strongly associated with clinical prognosis of hepatocellular carcinoma patients after curative resection. Cancer Med. 2019 Jul;8(7):3453-63.

31 Dewidar B, Meyer C, Dooley S, MeindlBeinker AN. TGF- $\beta$ in hepatic stellate cell activation and liver fibrogenesis-updated 2019. Cells. 2019 Nov 11;8(11):1419.

32 Wu K, Ding J, Chen C, Sun W, Ning BF, Wen $\mathrm{W}$, et al. Hepatic transforming growth factor beta gives rise to tumor-initiating cells and promotes liver cancer development. Hepatology. 2012 Dec;56(6):2255-67.

33 Yamazaki K, Masugi Y, Sakamoto M. Molecular pathogenesis of hepatocellular carcinoma: altering transforming growth factor-beta signaling in hepatocarcinogenesis. Dig Dis. 2011;29(3):284-8.

34 Calvisi DF. When good transforming growth factor-beta turns bad in hepatocellular carcinoma: Axl takes the stage. Hepatology. 2015 Mar;61(3):759-61.

35 Lamouille S, Xu J, Derynck R. Molecular mechanisms of epithelial-mesenchymal transition. Nat Rev Mol Cell Biol. 2014 Mar;15(3): 178-96.

36 van Zijl F, Zulehner G, Petz M, Schneller D, Kornauth C, Hau M, et al. Epithelial-mesenchymal transition in hepatocellular carcinoma. Future Oncol. 2009 Oct;5(8):1169-79. 
37 Reichl P, Dengler M, van Zijl F, Huber H, Fuhrlinger G, Reichel C, et al. Axl activates autocrine transforming growth factor-beta signaling in hepatocellular carcinoma. Hepatology. 2015 Mar;61(3):930-41.

38 Haider C, Hnat J, Wagner R, Huber $\mathrm{H}$, Timelthaler G, Grubinger M, et al. Transforming growth factor-beta and Axl induce CXCL5 and neutrophil recruitment in hepatocellular carcinoma. Hepatology. 2019 Jan; 69(1):222-36.

$39 \mathrm{Xu} \mathrm{J}$, Jia L, Ma H, Li Y, Ma Z, Zhao Y. Axl gene knockdown inhibits the metastasis properties of hepatocellular carcinoma via PI3K/AktPAK1 signal pathway. Tumour Biol. 2014 Apr;35(4):3809-17.

40 Lee HJ, Jeng YM, Chen YL, Chung L, Yuan RH. Gas6/Axl pathway promotes tumor invasion through the transcriptional activation of Slug in hepatocellular carcinoma. Carcinogenesis. 2014 Apr;35(4):769-75.

41 Jia Q, Dong Q, Qin L. CCN: core regulatory proteins in the microenvironment that affect the metastasis of hepatocellular carcinoma? Oncotarget. 2016 Jan 12;7(2):1203-14.

42 Li ZQ, Wu WR, Zhao C, Zhao C, Zhang XL, Yang Z, et al. CCN1/Cyr61 enhances the function of hepatic stellate cells in promoting the progression of hepatocellular carcinoma. Int J Mol Med. 2018 Mar;41(3):1518-28.

43 He L, Zhang J, Jiang L, Jin C, Zhao Y, Yang G, et al. Differential expression of Axl in hepatocellular carcinoma and correlation with tumor lymphatic metastasis. Mol Carcinog. 2010 Oct;49(10):882-91.

44 Lechertier T, Reynolds LE, Kim H, Pedrosa AR, Gómez-Escudero J, Muñoz-Félix JM, et al. Pericyte FAK negatively regulates Gas6/ Axl signalling to suppress tumour angiogenesis and tumour growth. Nat Commun. 2020 Jun 4;11(1):2810.

45 Li Y, Huang X, Zhang Q, Ma K. Phosphorylation of cMet tyrosine residues in murine ascitic hepatic cancer cell lines with different lymph node metastatic potentials. Mol Med Rep. 2013 Aug;8(2):655-61.

46 Takeo S, Arai H, Kusano N, Harada T, Furuya $\mathrm{T}$, Kawauchi S, et al. Examination of oncogene amplification by genomic DNA microarray in hepatocellular carcinomas: comparison with comparative genomic hybridization analysis. Cancer Genet Cytogenet. 2001 Oct 15;130(2):127-32.

47 Zhang Y, Gao X, Zhu Y, Kadel D, Sun H, Chen J, et al. The dual blockade of MET and VEGFR2 signaling demonstrates pronounced inhibition on tumor growth and metastasis of hepatocellular carcinoma. J Exp Clin Cancer Res. 2018 Apr 30;37(1):93.

48 Liu WT, Jing YY, Yu GF, Chen H, Han ZP, Yu DD, et al. Hepatic stellate cell promoted hepatoma cell invasion via the $\mathrm{HGF} / \mathrm{c}$-Met signaling pathway regulated by p53. Cell Cycle. 2016;15(7):886-94.

49 Szparecki G, Ilczuk T, Gabzdyl N, StockaŁabno E, Górnicka B. Expression of c-MET protein in various subtypes of hepatocellular adenoma compared to hepatocellular carcinoma and non-neoplastic liver in human tissue. Folia Biol. 2017;63(4):146-54.

50 Liu DL, Lu LL, Dong LL, Liu Y, Bian XY, Lian BF, et al. miR-17-5p and miR-20a-5p suppress postoperative metastasis of hepatocellular carcinoma via blocking HGF/ERBB3NF- $\kappa \mathrm{B}$ positive feedback loop. Theranostics. 2020;10(8):3668-83.

51 Li Y, Huang X, Zhong W, Zhang J, Ma K. Ganglioside GM3 promotes HGF-stimulated motility of murine hepatoma cell through enhanced phosphorylation of cMet at specific tyrosine sites and PI3K/Akt-mediated migration signaling. Mol Cell Biochem. 2013 Oct 1; 382(1):83-92.

52 Steinway SN, Dang H, You H, Rountree CB, Ding W. The EGFR/ErbB3 pathway acts as a compensatory survival mechanism upon cMet inhibition in human c-Met+ hepatocellular carcinoma. PLoS One. 2015;10(5): e0128159.

53 Topel H, Bagirsakci E, Comez D, Bagci G, Cakan-Akdogan G, Atabey N. IncRNA HOTAIR overexpression induced downregulation of c-Met signaling promotes hybrid epithelial/mesenchymal phenotype in hepatocellular carcinoma cells. Cell Commun Signal. 2020 Jul 11;18(1):110.

54 Rhee H, Kim HY, Choi JH, Woo HG, Yoo JE, $\mathrm{Nahm} \mathrm{JH}$, et al. Keratin 19 expression in hepatocellular carcinoma is regulated by fibroblast-derived HGF via a MET-ERK1/2-AP1 and SP1 axis. Cancer Res. 2018 Apr 1;78(7): 1619-31.

55 Fu R, Jiang S, Li J, Chen H, Zhang X. Activation of the HGF/c-MET axis promotes lenvatinib resistance in hepatocellular carcinoma cells with high c-MET expression. Med Oncol. 2020 Mar 12;37(4):24.

56 Dang H, Steinway SN, Ding W, Rountree CB. Induction of tumor initiation is dependent on CD44s in c-Met+ hepatocellular carcinoma. BMC Cancer. 2015 Mar 21;15:161.

$57 \mathrm{Hu}$ J, Che L, Li L, Pilo MG, Cigliano A, Ribback S, et al. Co-activation of AKT and c-Met triggers rapid hepatocellular carcinoma development via the mTORC1/FASN pathway in mice. Sci Rep. 2016 Feb 9;6:20484.

58 Liang Y, Feng Y, Zong M, Wei XF, Lee J, Feng $\mathrm{Y}$, et al. $\beta$-catenin deficiency in hepatocytes aggravates hepatocarcinogenesis driven by oncogenic $\beta$-catenin and MET. Hepatology. 2018 May;67(5):1807-22.

59 Takeda S, Liu H, Sasagawa S, Dong Y, Trainor $\mathrm{PA}$, Cheng EH, et al. HGF-MET signals via the MLL-ETS2 complex in hepatocellular carcinoma. J Clin Invest. 2013 Jul;123(7):3154-65.

60 Piguet AC, Medová M, Keogh A, Glück AA, Aebersold DM, Dufour JF, et al. Impact of MET targeting on tumor-associated angiogenesis and growth of MET mutations-driven models of liver cancer. Genes Cancer. 2015 Jul;6(7-8):317-27.

61 Leung CON, Tong M, Chung KPS, Zhou L, Che $\mathrm{N}$, Tang $\mathrm{KH}$, et al. Overriding adaptive resistance to sorafenib via combination therapy with SHP2 blockade in hepatocellular carcinoma. Hepatology. 2019 Oct 14;72(1):155-68.

62 Chen S, Xia X. Long noncoding RNA NEAT1 suppresses sorafenib sensitivity of hepatocellular carcinoma cells via regulating miR-335c-Met. J Cell Physiol. 2019 Apr 1. Epub ahead of print.

63 Han P, Li H, Jiang X, Zhai B, Tan G, Zhao D, et al. Dual inhibition of Akt and c-Met as a second-line therapy following acquired resistance to sorafenib in hepatocellular carcinoma cells. Mol Oncol. 2017 Mar;11(3):320-34.

64 Chen HA, Kuo TC, Tseng CF, Ma JT, Yang ST, Yen CJ, et al. Angiopoietin-like protein 1 antagonizes MET receptor activity to repress sorafenib resistance and cancer stemness in hepatocellular carcinoma. Hepatology. 2016 Nov;64(5):1637-51.

65 Xiang Q, Chen W, Ren M, Wang J, Zhang H, Deng DY, et al. Cabozantinib suppresses tumor growth and metastasis in hepatocellular carcinoma by a dual blockade of VEGFR 2 and MET. Clin Cancer Res. 2014 Jun 1;20(11): 2959-70

66 Xiang QF, Zhan MX, Li Y, Liang H, Hu C, Huang YM, et al. Activation of MET promotes resistance to sorafenib in hepatocellular carcinoma cells via the AKT/ERK1/2EGR1 pathway. Artif Cells Nanomed Biotechnol. 2019 Dec;47(1):83-9.

67 Myers KV, Amend SR, Pienta KJ. Targeting Tyro3, Axl and MerTK (TAM receptors): implications for macrophages in the tumor microenvironment. Mol Cancer. 2019 May 14; 18(1):94.

68 Dong N, Shi X, Wang S, Gao Y, Kuang Z, Xie $Q$, et al. M2 macrophages mediate sorafenib resistance by secreting HGF in a feed-forward manner in hepatocellular carcinoma. Br J Cancer. 2019 Jul;121(1):22-33.

69 Zhou SL, Dai Z, Zhou ZJ, Wang XY, Yang $\mathrm{GH}$, Wang Z, et al. Overexpression of CXCL5 mediates neutrophil infiltration and indicates poor prognosis for hepatocellular carcinoma. Hepatology. 2012 Dec;56(6): 2242-54.

70 Donskov F. Immunomonitoring and prognostic relevance of neutrophils in clinical trials. Semin Cancer Biol. 2013 Jun;23(3):200-7.

71 Tecchio C, Scapini P, Pizzolo G, Cassatella MA. On the cytokines produced by human neutrophils in tumors. Semin Cancer Biol. 2013 Jun;23(3):159-70.

72 Sionov RV, Fridlender ZG, Granot Z. The multifaceted roles neutrophils play in the tumor microenvironment. Cancer Microenviron. 2015 Dec;8(3):125-58.

73 Fridlender ZG, Sun J, Kim S, Kapoor V, Cheng $\mathrm{G}$, Ling $\mathrm{L}$, et al. Polarization of tumorassociated neutrophil phenotype by TGF-beta: "N1" versus "N2" TAN. Cancer Cell. 2009 Sep 8;16(3):183-94.

$74 \mathrm{Li} \mathrm{H}, \mathrm{Li} \mathrm{CW}$, Li X, Ding Q, Guo L, Liu S, et al. MET inhibitors promote liver tumor evasion of the immune response by stabilizing PDL1. Gastroenterology. 2019 May;156(6):1849-61. e13. 
75 Kelley RK, Ryoo BY, Merle P, Park JW, Bolondi L, Chan SL, et al. Second-line cabozantinib after sorafenib treatment for advanced hepatocellular carcinoma: a subgroup analysis of the phase 3 CELESTIAL trial. ESMO Open. 2020 Aug;5(4):e000714.

76 Guo Z, Li Y, Zhang D, Ma J. Axl inhibition induces the antitumor immune response which can be further potentiated by PD-1 blockade in the mouse cancer models. Oncotarget. 2017 Oct 27;8(52):89761-74.

77 Ludwig KF, Du W, Sorrelle NB, Wnuk-Lipinska K, Topalovski M, Toombs JE, et al. Smallmolecule inhibition of Axl targets tumor immune suppression and enhances chemotherapy in pancreatic cancer. Cancer Res. 2018 Jan 1;78(1):246-55.

78 Sadahiro H, Kang KD, Gibson JT, Minata M, $\mathrm{Yu} \mathrm{H}$, Shi J, et al. Activation of the receptor tyrosine kinase AXL regulates the immune microenvironment in glioblastoma. Cancer Res. 2018 Jun 1;78(11):3002-13.

79 Holtzhausen A, Harris W, Ubil E, Hunter DM, Zhao J, Zhang Y, et al. TAM family receptor kinase inhibition reverses MDSC-mediated suppression and augments anti-PD-1 therapy in melanoma. Cancer Immunol Res. 2019 Oct; $7(10): 1672-86$.

80 Terry S, Abdou A, Engelsen AST, Buart S, Dessen P, Corgnac S, et al. AXL targeting overcomes human lung cancer cell resistance to NK- and CTL-mediated cytotoxicity. Cancer Immunol Res. 2019 Sep 5;7(11):1789-802.

81 Lu X, Horner JW, Paul E, Shang X, Troncoso P, Deng $P$, et al. Effective combinatorial immunotherapy for castration-resistant prostate cancer. Nature. 2017 Mar 30;543(7647):728-32.
82 Wang Q, Guldner IH, Golomb SM, Sun L, Harris JA, Lu X, et al. Single-cell profiling guided combinatorial immunotherapy for fast-evolving CDK4/6 inhibitor-resistant HER2-positive breast cancer. Nat Commun. 2019 Aug 23;10(1):3817.

83 Agarwal N, Loriot Y, McGregor BA, Dreicer R, Dorff TB, Maughan BL, et al. Cabozantinib in combination with atezolizumab in patients with metastatic castration-resistant prostate cancer: results of cohort 6 of the COSMIC-021 study. J Clin Oncol. 2020;38(15_Suppl):5564.

84 Choueiri TK, Powles T, Burotto M, Bourlon MT, Zurawski B, Oyervides Juárez VM, et al. 696O_PR nivolumab + cabozantinib vs sunitinib in first-line treatment for advanced renal cell carcinoma: first results from the randomized phase III CheckMate 9ER trial. Ann Oncol. 2020 Sept 1;31:S1159.

85 Neal JW, Lim FL, Felip E, Gentzler RD, Patel SB, Baranda J, et al. Cabozantinib in combination with atezolizumab in non-small cell lung cancer (NSCLC) patients previously treated with an immune checkpoint inhibitor: results from cohort 7 of the COSMIC-021 study. J Clin Oncol. 2020;38(15_Suppl):9610.

86 Pal S, Tsao CK, Suarez C, Kelly W, Pagliaro L, Vaishampayan UN, et al. $702 \mathrm{O}$ cabozantinib (C) in combination with atezolizumab (A) as first-line therapy for advanced clear cell renal cell carcinoma (ccRCC): results from the COSMIC-021 study. Ann Oncol. 2020 Sept 1; 31:S554.

87 Pal SK, Agarwal N, Loriot Y, Rodriguez CS, Singh P, Vaishampayan UN, et al. Cabozantinib in combination with atezolizumab in urothelial carcinoma previously treated with platinum-containing chemotherapy: results from cohort 2 of the COSMIC-021 study. J Clin Oncol. 2020;38(15_Suppl):5013.
88 Yau T, Zagonel V, Santoro A, Acosta-Rivera M, Choo SP, Matilla A, et al. Nivolumab (NIVO) + ipilimumab (IPI) + cabozantinib $(\mathrm{CABO})$ combination therapy in patients (pts) with advanced hepatocellular carcinoma (aHCC): results from CheckMate 040. J Clin Oncol. 2020;38(4_Suppl):478.

89 Kwilas AR, Ardiani A, Donahue RN, Aftab DT, Hodge JW. Dual effects of a targeted small-molecule inhibitor (cabozantinib) on immune-mediated killing of tumor cells and immune tumor microenvironment permissiveness when combined with a cancer vaccine. J Transl Med. 2014 Nov 13;12:294.

90 Tripathi M, Nandana S, Billet S, Cavassani KA, Mishra R, Chung LWK, et al. Modulation of cabozantinib efficacy by the prostate tumor microenvironment. Oncotarget. 2017 Oct 20; 8(50):87891-902.

91 Patnaik A, Swanson KD, Csizmadia E, Solanki A, Landon-Brace N, Gehring MP, et al. Cabozantinib eradicates advanced murine prostate cancer by activating antitumor innate immunity. Cancer Discov. 2017 Jul;7(7):750-65.

92 Rimassa L, Assenat E, Peck-Radosavljevic M, Pracht M, Zagonel V, Mathurin P, et al. Tivantinib for second-line treatment of METhigh, advanced hepatocellular carcinoma (METIV-HCC): a final analysis of a phase 3, randomised, placebo-controlled study. Lancet Oncol. 2018 May;19(5):682-93.

93 Exelixis, Ipsen. Exelixis and Ipsen announce cabozantinib in combination with an immune checkpoint inhibitor significantly improved progression-free survival in phase 3 COSMIC-312 pivotal trial in patients with previously untreated advanced liver cancer. 2021. 